\title{
The Structure and Function of the $\mathrm{Na}$,K-ATPase Isoforms in Health and Disease
}

\author{
Michael V. Clausen, Florian Hilbers and Hanne Poulsen* \\ Department of Molecular Biology and Genetics, Aarhus University, Aarhus, Denmark
}

The sodium and potassium gradients across the plasma membrane are used by animal cells for numerous processes, and the range of demands requires that the responsible ion pump, the Na,K-ATPase, can be fine-tuned to the different cellular needs. Therefore, several isoforms are expressed of each of the three subunits that make a Na,K-ATPase, the alpha, beta and FXYD subunits. This review summarizes the various roles and expression patterns of the Na,K-ATPase subunit isoforms and maps the sequence variations to compare the differences structurally. Mutations in the Na,K-ATPase genes encoding alpha subunit isoforms have severe physiological consequences, causing very distinct, often neurological diseases. The differences in the pathophysiological effects of mutations further underline how the kinetic parameters, regulation and proteomic interactions of the Na,K-ATPase isoforms are optimized for the individual cellular needs.

Edited by:

Mario Diaz,

University of La Laguna, Spain

Reviewed by:

Pablo Martín-Vasallo,

University of La Laguna, Spain

Tomas Obsil,

Charles University, Czechia Lijun Catherine Liu,

University of Toledo, United States

*Correspondence: Hanne Poulsen hp@mb.au.dk

Specialty section:

This article was submitted to Membrane Physiology and Membrane

Biophysics,

a section of the journal

Frontiers in Physiology

Received: 01 February 2017 Accepted: 18 May 2017 Published: 06 June 2017

Citation:

Clausen MV, Hilbers F and Poulsen H (2017) The Structure and Function of the Na,K-ATPase Isoforms in Health and Disease. Front. Physiol. 8:371.

doi: 10.3389/fphys.2017.00371
Keywords: Na, K-ATPase, structure, expression, isoforms, subunits, disease

\section{INTRODUCTION}

During the evolution of life, most living cells have maintained a similar ionic composition of their cytoplasms, including low calcium, low sodium, high potassium, and neutral $\mathrm{pH}$ (Mulkidjanian et al., 2012). When the extracellular ionic concentrations are significantly different, it requires perpetual ion pump activity to uphold the intracellular concentrations, which are important for numerous of the cell's enzymatic functions. Furthermore, much energy is stored in the ionic gradients across the plasma membrane, and the steep sodium and potassium gradients in animal cells are used to facilitate secondary transport of molecules (sugars, neurotransmitters, amino acids, metabolites) and other ions $\left(\mathrm{H}^{+}, \mathrm{Ca}^{2+}, \mathrm{Cl}^{-}\right)$. The ion gradients are also used for rapid signaling by opening of sodium or potassium selective channels in the plasma membrane in response to extracellular signals or the membrane potential.

Many organs use the sodium and potassium gradients for their specialized functions. In the kidneys, the $\mathrm{Na}, \mathrm{K}$-ATPase is highly expressed, an estimate says up to 50 million pumps per cell in the distal convoluted tubule (El Mernissi and Doucet, 1984), because the sodium gradient is utilized by the main kidney functions, to filter the blood of waste products, to reabsorb glucose and amino acids, to regulate electrolytes and to maintain $\mathrm{pH}$. In sperm cells, the regulation of ions and membrane potential is crucial for motility and the acrosome reaction, and sperm cells express a unique Na,K-ATPase isoform, which is essential for male fertility (Jimenez et al., 2011a). Not least the brain has a massive demand for Na,K-ATPase activity, since neurons rely on the pump to reverse postsynaptic sodium flux, to reestablish the sodium and potassium gradients used to fire action potentials, and in astrocytes, the sodium gradient drives neurotransmitter reuptake. In gray matter, it is estimated that housekeeping like synthesis of proteins and other molecules use just a quarter of the energy, while the rest is consumed by Na,K-ATPases (Attwell and Laughlin, 2001). 


\section{CARDIOTONIC STEROIDS}

The vital importance of the Na,K-ATPase for animals makes it a natural target for toxins produced by plants or animals that want to avoid being eaten. At least 12 different plant families and several species of the Bufo toads produce $\mathrm{Na}, \mathrm{K}$-ATPase inhibitors, the so-called cardiotonic steroids (Gao et al., 2011). Plant cells have no endogenous $\mathrm{Na}, \mathrm{K}$-ATPase, since they use a proton gradient to energize their membranes, so $\mathrm{Na}, \mathrm{K}$-ATPase inhibitors are not toxic to them.

Several insect species feed on plants with cardiotonic steroids and store the toxins to make themselves poisonous (Zhen et al., 2012). The poisonous insects and toads can, nonetheless, become prey to other animals, including reptiles, hedgehogs, and rodents. All animals that produce or ingest cardiotonic steroids tolerate the toxin because of specific mutations in their Na,K-ATPase encoding genes that make the pumps insensitive to the inhibitor (Ujvari et al., 2015), a classical example of an evolutionary arms race, where one species develops a weapon, and then its predator develops a defense against it.

Cardiotonic steroids like digitalis from the foxglove plant have been used to treat heart conditions for centuries. They are recommended for atrial fibrillation and reduce hospital admission for heart failure patients, but have not been shown to affect mortality rates (Ziff and Kotecha, 2016). The mechanismof-action of digitalis is still a matter of debate. It has been believed that inhibition of the Na,K-ATPase in cardiomyocytes raises cytoplasmic sodium levels, thereby inhibiting the sodiumcalcium exchanger and raising cytoplasmic calcium levels, which is imagined to have a direct effect on the heart's contractility, but there is also evidence to suggest that digitalis strengthens the parasympathetic nervous system by vagal activation and slows heart rate (Ziff and Kotecha, 2016).

At non-saturating levels (5-10 nM), cardiotonic steroids have been suggested to act as ligands and the $\mathrm{Na}, \mathrm{K}$-ATPase as a receptor that initiates intracellular signaling via e.g., the inositol 1,4,5-triphosphate receptor and the Src kinase to promote cellular proliferation. In the body, cardiotonic steroids may arise from medication, but low levels of endogenous cardiotonic steroids have also been measured (Aperia et al., 2016). It remains controversial what the physiological significance of $\mathrm{Na}$, K-ATPase signaling may be, and transcriptome differences in response to cardiotonic steroids were only seen if the relative intracellular concentrations of sodium and potassium changed, i.e., if there was a direct effect on the ion pumping mechanism (Klimanova et al., 2017).

\section{THE BASIC MECHANISM OF ION TRANSPORT}

Cardiotonic steroids bind the Na,K-ATPase from the extracellular side in the suggested ion exchange pathway as revealed by the crystal structure of a high-affinity binding complex between the cardiotonic steroid digoxin and $\mathrm{Na}, \mathrm{K}-$ ATPase purified from pig kidney (Laursen et al., 2015, Figure 1). The complex contains three protein subunits, namely the ten transmembrane (TM) helix alpha subunit and the single TM beta and FXYD subunits. The beta subunit has a large, glycosylated extracellular part, and for the smaller FXYD subunit, only the TM part is resolved in the structure. The alpha subunit has three cytoplasmic domains, the nucleotide binding $(\mathrm{N})$, the phosphorylation $(\mathrm{P})$ and the actuator $(\mathrm{A})$ domains, which function as the kinase, the substrate and the phosphatase, respectively, in the catalytic cycle, when ATP is hydrolyzed (Figure 2). A conserved aspartate in the P-domain is phosphorylated and dephosphorylated during the cycle, and the movements of the cytoplasmic domains cause the connected TM helices to bind and release the pump's substrates in response. The $\mathrm{Na}, \mathrm{K}$-ATPase was the founding member of the P-type ATPase family (Skou, 1957) whose members share this basic mechanism to transport numerous different cations and even lipids. In addition to the ouabain-bound $\mathrm{Na}, \mathrm{K}$-ATPase, crystal structures of two major steps in the catalytic cycle have been solved, namely of the potassium (Morth et al., 2007; Shinoda et al., 2009) and sodium (Kanai et al., 2013; Nyblom et al., 2013) occluded forms (Figure 2).

The transport of ions against their concentration gradients requires that the transmembrane ion binding site acts like a space shuttle airlock with gates on either side of which at least one is always locked to avoid the energetically favored flow of ions in the opposite direction. When the Na,K-ATPase opens toward the cytoplasm, TM1 is believed to slide up (as in the related calcium pump SERCA, Winther et al., 2013) and allow three sodium ions to access the high-affinity binding sites in the middle of the membrane, where negative charges on aspartate and glutamate residues compensate for the charges of the positively charged ions (Figure 2). When bound, the inner gate closes to form an occluded pump, and the P-domain is phosphorylated by ATP. The pump is said to be in the E1 form when it has high affinity for sodium, and in the E2 form when it has high affinity for potassium. The transition from phosphorylated E1 (called E1P) to $\mathrm{E} 2 \mathrm{P}$ is coupled to release of $\mathrm{ADP}$, opening of the outer gate and release of the three sodium ions to the extracellular side. It is proposed that a proton from the cytoplasm promotes the sodium release and compensates for negative charge at the ion binding site unique for sodium, the so-called site III, when sodium is released (Poulsen et al., 2010). Potassium can then bind from the extracellular side, the outer gate closes to occlude the two potassium ions, and the aspartate in the P-domain is dephosphorylated. Binding of ATP, a transition back to the E1 form, and opening of the inner gate lead to cytoplasmic release of the proton in site III and of the potassium ions in sites I and II, and the pump is ready for another cycle (Figure 2).

\section{ISOFORM EXPRESSION, FUNCTION AND PHYSIOLOGY}

The first indication that there is more than one isoform of the Na,K-ATPase subunits came from titration with ouabain on mouse brain preparations, which showed a biphasic curve of ATPase activity (Marks and Seeds, 1978). It was later found that the biphasic curve, which is also found in rat, is due to 


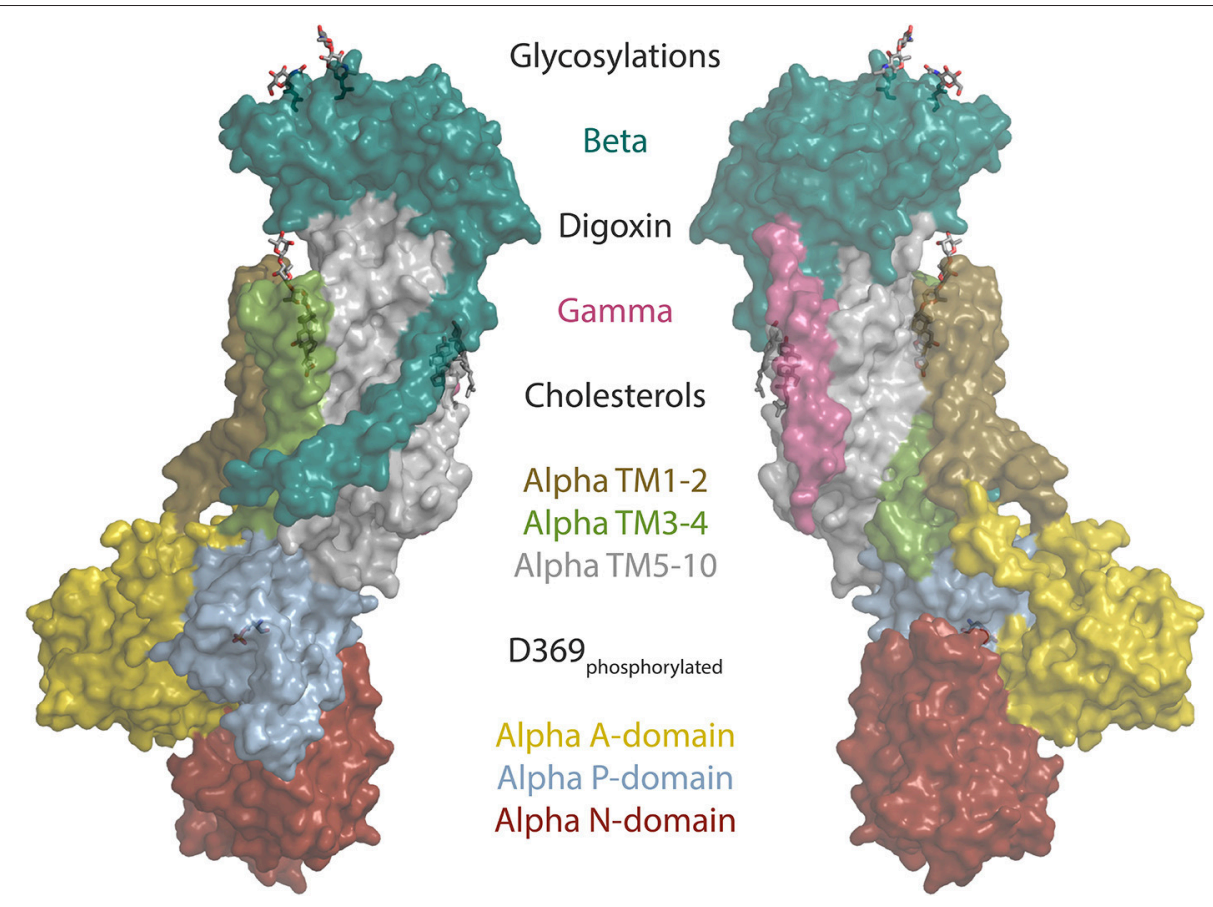

FIGURE 1 | The structure of the sodium pump. Surface representation of the digoxin bound alpha1 isoform structure from pig (Laursen et al., 2015) (PDB ID: 4RET). Sodium pump subunits and domains are shown in colors as indicated. The two beta glycosylations, digoxin, two cholesterols and the phosphorylated aspartate (D369) are shown as sticks.

a specific reduction in ouabain affinity (low $\mathrm{mM}$ ) of alpha1 in rodents that makes it easily distinguished from the two high affinity isoforms found in brain, alpha2, and alpha3 (low $\mu \mathrm{M}$ affinities). The primary sequences of the alpha isoforms are well conserved: alpha1, 2, and 3 are about $87 \%$ identical to each other and about $78 \%$ identical to the sperm-specific alpha4 (Shamraj and Lingrel, 1994). Between species, the identity percentages of alpha1, 2, and 3 are in the high nineties and for alpha4 in the low eighties (Clausen et al., 2011). Mapping the isoform differences on homology models of each alpha (Figure 3) shows that the variation is generally found at the surface of the protein, while the ion binding interior of the membrane domain and the linkers to the cytoplasmic domains are highly conserved. The most diverse part of the protein is the surface of the $\mathrm{N}$-domain, especially in alpha4. The basic function of the pump will depend most strongly on the interior parts where ions are transported in response to the ATP hydrolysis, while differences on the surface allow each isoform to have its own protein-protein interaction networks.

In addition to the four alpha isoforms, mammals express three beta and seven FXYD subunit isoforms. The combination of alpha1 and beta1 is expressed most widely (table), and any alpha can be expressed with any beta to yield a functional pump in Xenopus oocytes (Crambert et al., 2000; Hilbers et al., 2016), though in vivo the associations may be more selective (Tokhtaeva et al., 2012; Habeck et al., 2016).

The different isoforms have different kinetic properties and affinities. Depending on the assay used, the details can vary, but for example for the alphas, there is general consensus that alpha1 has relatively high apparent potassium affinity, and alpha3 relatively low sodium affinity (Blanco, 2005). The beta and FXYD subunits further affect the functional properties (Arystarkhova and Sweadner, 2016; Hilbers et al., 2016), so the different subunits allow cells to have Na,K-ATPase activity with optimized functional characteristics. In addition, the subunits differ in how they are trafficked to and localized in the membrane, which posttranslational modifications they are subject to, and importantly what cellular partners they interact with. Therefore, the distinct expression profiles of the Na,K-ATPase subunits enable fine-tuning in time and tissues of the pumping activity (Table).

Since the ionic gradients are of vital importance for any organ, disturbance of the Na,K-ATPase activity has been implicated in many pathophysiological conditions, including cancer (Durlacher et al., 2015), diabetes (Vague et al., 2004), and heart failure (Schwinger et al., 2003), and the pump has been suggested as a potential chemotherapy target (Alevizopoulos et al., 2014), though evidence is still lacking for its efficacy (Durlacher et al., 2015).

\section{ALPHA1}

The alphal subunit is essentially omnipresent at the tissue and cellular levels. One organ that relies heavily on sodium and potassium gradients is the heart, where the rhythmic action potentials and accompanying calcium fluxes determine the muscle contractions. All animal hearts examined express alpha1, while it varies between species if it is the only 

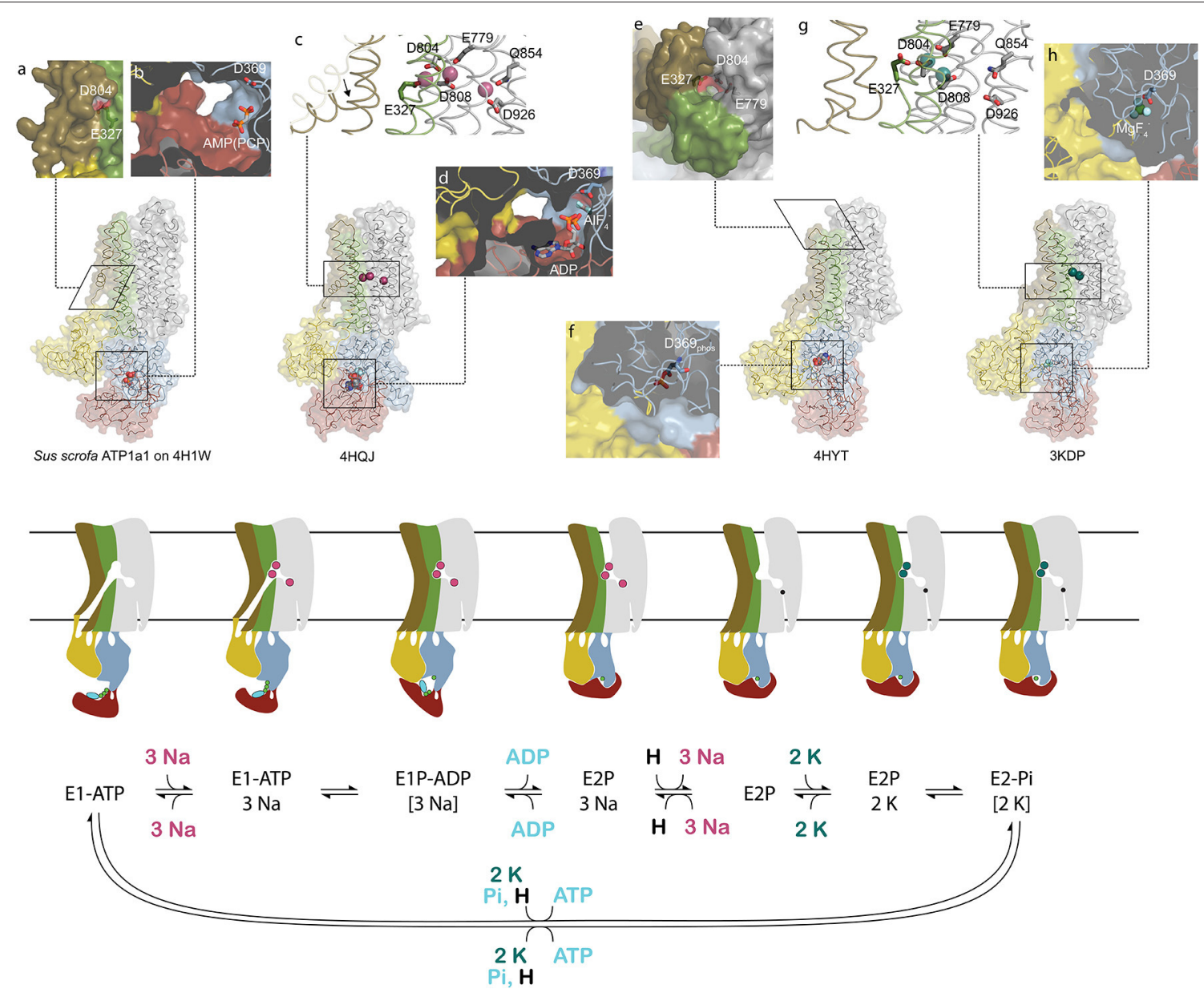

FIGURE 2 | Conformational changes during the sodium pump catalytic cycle. Three sodium pump structures and a homology model are positioned in accordance with the catalytic cycle shown below as both cartoon and reaction scheme. The eight inserts labeled with small letters highlight important structural details. The homology model of pig alpha1 on the SERCA E1-ATP state (Winther et al., 2013) (PDB ID: 4H1W) shows an inwardly opened conformation with access to the ion-binding sites, here visualized by D804 and E327 (a). In the structure, only the beta and gamma phosphates of the non-hydrolysable ATP analog AMPPCP are resolved and demonstrate a non-primed positioning for reaction with D369 (b). After binding of three sodium ions, TM1 rearranges to a position that blocks the cytoplasmic entrance pathway (arrow in c), and the cytoplasmic domains tighten around the nucleotide that reacts with D369 (d). Following sodium occlusion ADP is released and an extracellular pathway allows the exit of the three sodium ions. In the externally opened conformation, here imitated by the ouabain bound structure 4HYT shown without the inhibitor, three ion-binding residues are directly visible from the outside (e), and the intracellular domains are completely wrapped around the phosphorylated D369 (f). Binding of two extracellular potassium ions (g) initiates closure of the extracellular gate and dephosphorylation of D369 (h). The narrow pathway from the cytoplasm to the sodium specific binding site in the cartoon representation shows the proposed C-terminal proton path utilized for charge conservation. Color coding as in Figure 1.

isoform or if alpha2 and/or alpha3 can be detected (Sweadner et al., 1994; McDonough et al., 2002; Dostanic et al., 2004; Henriksen et al., 2013, Table). In human hearts, all three isoforms are expressed, and in failing human hearts the protein levels of alpha1 and alpha3 are reduced $30-40 \%$ in the left ventricle compared to non-failing hearts (Schwinger et al., 1999), and at the RNA level, the left and right ventricles of failing hearts show around 50\% reduction in transcripts encoding alpha1 and alpha2 (Borlak and Thum, 2003). An increase in the intracellular sodium concentration due to lower levels of $\mathrm{Na}, \mathrm{K}$-ATPase will likely decrease calcium export by the $\mathrm{Na}^{+} / \mathrm{Ca}^{2+}$-exchanger, which may be the main extrusion pathway in cardiomyocytes. The downregulation of
$\mathrm{Na}, \mathrm{K}$-ATPases is also a probable reason for higher sensitivity to cardiotonic steroids in failing hearts (Shamraj et al., 1993).

Several physiological processes depend on a very strict regulation of the subcellular localization of alpha1. Cavities and surfaces in the body are lined by sheets of polarized epithelial cells that have distinct membrane domains; an apical membrane that faces the lumen and a basolateral membrane that is oriented away from the lumen. Depending on the physiological role of an epithelial sheet, the cellular sorting machinery makes sure that alphal ends up in either the apical or the basolateral membrane.

When the intention is to minimize bodily loss of sodium through e.g., urine and sweat, alphal is sent to the basolateral 


Unique in this isoform
conserved in others
Unique in this isoform
not conserved in others
Shared with Alpha1
Shared with Alpha2
Shared with Alpha3
Shared with Alpha4

membrane of the epithelial cells as seen in the renal tubular system (Caplan et al., 1986) and in the secretory coils of sweat glands (Zhang et al., 2014), where sodium reuptake is driven by channels and secondary transporters.

To maintain a low level of potassium while indirectly supplying water to the cerebrospinal fluid of the central nervous system, the epithelial cells that line the choroid plexus sort alpha1 to the apical membrane (Gundersen et al., 1991; Brown et al., 2004). The same strategy of apical alphal sorting is utilized in the eye where retinal pigment epithelium supplies the fluid of the subretinal space with the high sodium concentration needed to maintain the dark current that keeps photoreceptor cells depolarized in the absence of light (Miller et al., 1978; Sparrow et al., 2010).

\section{ALPHA2}

The alpha2 isoform is predominantly expressed in muscle (heart and skeletal) and brain (in astrocytes and glia cells). It is noteworthy that while astrocytes co-cultured with neurons readily express alpha2, purified astrocytes grown without neurons only rarely express it (Peng et al., 1998). With a relatively high sensitivity to voltage (Crambert et al., 2000; Horisberger and Kharoubi-Hess, 2002; Larsen et al., 2014; Clausen et al., 2016) and in combination with beta2, a remarkably reduced affinity for potassium $\left(\mathrm{K}^{+} \mathrm{K}_{0.5} 3 \mathrm{mM}\right.$, other isoforms have $\mathrm{K}_{0.5} \sim 1 \mathrm{mM}$, Crambert et al., 2000; Larsen et al., 2014), the alpha2beta2 complex in glia and astrocytes seems perfectly geared for clearance of potassium after intense neuronal activity, being maximally active when the potassium concentration is high, and the membrane potential depolarized.

In the heart, alpha2 preferentially assembles with beta2 and specifically localizes to the T-tubular membranes, while alphalbeta 1 is more uniformly distributed in both T-tubular membranes and external sarcolemma membranes (Habeck et al., 2016). The alpha 2 subunit localizes close to the $\mathrm{Na}^{+} / \mathrm{Ca}^{2+}$ exchanger in contractile tissue and may thereby indirectly serve to assist the regulation of calcium levels (Juhaszova and Blaustein, 1997). Similar to the suggested role in glia cells, the high voltage sensitivity and low potassium affinity of alpha2beta2 are proposed to ensure that additional $\mathrm{Na}, \mathrm{K}$ ATPase activity is available during the long-lasting cardiac action potential (Stanley et al., 2015; Habeck et al., 2016). In skeletal muscle, the alpha2 activity is rapidly controlled in response to changes in muscle use, suggesting that it may be adapted to reacting on dynamic changes in muscle activity (Kravtsova et al., 2016).

\section{ALPHA3}

Alpha3 is highly expressed in the brain with a main localization in neuronal projections (Bottger et al., 2011) and to some extend in dendritic spines (Kim et al., 2007; Blom et al., 2016). During intense neuronal activity, the concentration of sodium in dendrites and spines can increase dramatically, estimates as high as $100 \mathrm{mM}$ have been proposed (Rose and Konnerth, 2001), and the required clearance of intracellular sodium is mainly attributed to alpha3 (Azarias et al., 2013), which has relatively low sodium affinity, 25-50 mM, compared to $\mathrm{Na}^{+} \mathrm{K}_{0.5}$ of approximately $10 \mathrm{mM}$ for other isoforms (Zahler et al., 1997; Blanco and Mercer, 1998; Crambert et al., 2000). The alpha3-containing pumps in neurons thus appear to be optimized for high intensity neuronal firing.

Interestingly, several studies of disease mechanisms have found that neurodegenerative effects may be caused by direct interactions with alpha3. In Alzheimer's disease, amyloid-beta can cause neurodegeneration, and the same is true for alphasynuclein in Parkinson's disease. Amyloid-beta as well as alphasynuclein assemblies were found to interact with alpha3, and mapping of the interaction domain located a specific extracellular loop in the pump as the target in both cases (Ohnishi et al., 2015; Shrivastava et al., 2015). Furthermore, misfolded SOD1 protein, which is associated with amyotrophic lateral sclerosis, can bind an intracellular domain of alpha3 and inhibit the pump function (Ruegsegger et al., 2016). 
Alpha3 is also highly expressed in the human heart; interestingly with gender-specific differences: the relative expression of alpha3 to alphal is several-fold higher in men than in women as judged from RNA levels (Gaborit et al., 2010).

\section{ALPHA4}

Spermatozoa are exceedingly specialized cells unique in their dependence on being able to thrive and carry out complex tasks inside other organisms. Furthermore, they are subject to a more profound evolutionary pressure than other cells, because only a single spermatozoon from a batch of hundreds of millions has a chance of fertilizing an egg, and only mutations that make better spermatozoa count in this race. The competitive spermatozoa evolution is evident from the high number of unique sperm cell proteins, particularly membrane proteins (Dorus et al., 2010). One of the sperm specific proteins is the alpha4 isoform of the sodium pump (Hlivko et al., 2006; McDermott et al., 2012), and the strong evolutionary pressure on sperm proteins is very apparent for alpha4, which is the most divergent of the $\mathrm{Na}, \mathrm{K}$ ATPase alpha subunits, both when compared with the other three alpha isoforms (Figure 3), and when compared between different species (Clausen et al., 2011). While alpha 4 is considered a sperm specific $\mathrm{Na}, \mathrm{K}$-ATPase, a smaller protein from human skeletal muscle cross react with an alpha4 antisera (Sugiura et al., 2005), and mRNA that hybridize with alpha4 probes are present in human and mouse skeletal muscle (Keryanov and Gardner, 2002).

Although sperm cells express alphal in addition to alpha4, male mice are completely sterile if they lack alpha4, and their spermatozoa are unable to fertilize eggs in vitro although their viability is unaffected (Jimenez et al., 2011a). Lack of alpha4 reduces sperm motility, depolarizes the membrane potential and increases intracellular sodium (Jimenez et al., 2011a), whereas overexpression of alpha4 increases their motility (Jimenez et al., 2011b; McDermott et al., 2015).

At the biophysical level, when compared with the other isoforms in a cell free system, alpha 4 has low $\mathrm{K}_{0.5}$ for ouabain and sodium, and regular for potassium (Blanco et al., 1999). When studied in a cellular system, alpha4 is less affected by changes in voltage, extracellular sodium and temperature than alpha1 (Clausen et al., 2016).

If greater evolutionary pressure has optimized alpha4 to increase the probability that spermatozoa reach and fertilize an egg in the female oviduct, there could be specific parameters that make this pump more suitable for the task than the other isoforms. Interestingly it has been demonstrated that as spermatozoa capacitate in the female genital tract, the catalytic activity of alpha 4 is up-regulated due to an increased availability of pumps in the membrane (Jimenez et al., 2012), suggesting that alpha4 supports the hyperpolarization and decreased intracellular sodium concentration characteristic of capacitated spermatozoa. An alternative, and not necessarily conflicting, hypothesis is that since pumps in the membrane of spermatozoa experience dramatic changes in e.g., extracellular sodium levels and membrane potential as the cell passes from testis to oviduct, it could be advantageous with a pump that, like alpha4, responds less to environmental alterations (Clausen et al., 2016).

\section{BETAS}

The Na,K-ATPase beta subunit is part of the functional core of the pump and is required for its trafficking to the plasma membrane. The sequence identity of the three human isoforms are 39\% (beta1 and 2), 36\% (beta1 and 3), and 47\% (beta2 and 3). It has a small (30 amino acid) N-terminal, intracellular domain, a TM helix, and a larger ( $\sim 240$ amino acids) C-terminal, extracellular domain. Like the alpha isoforms, the different beta isoforms have distinct tissue and cell-type specific expression profiles (Table 1). The beta 2 isoform was originally found in glia where it is involved in cell-cell contacts and hence it was initially called Adhesion Molecule On Glia (AMOG, Antonicek et al., 1987; Martin-Vasallo et al., 1989; Gloor et al., 1990).

There are three conserved disulfide bonds in the extracellular domain, which are important for forming a stable pump (Noguchi et al., 1994), and the domain has three, eight, and two glycosylation sites in beta1, 2, and 3, respectively. Removal of the glycosylations causes retention in the endoplasmatic reticulum of beta2, but not of beta1 or 3, suggesting that the glycosylations play individual roles in the different isoforms (Tokhtaeva et al., 2010).

Betal may further respond to oxidative stress by glutathionylation of a cysteine in the middle of its transmembrane helix, a cysteine not found in the other betas (Rasmussen et al., 2010). In vitro studies have shown that the E1 state of the enzyme favors the cysteine to be glutathionylated more than the E2 state (Garcia et al., 2015).

Functionally, beta 2 has the strongest effects on the kinetic properties of the pump, reducing the apparent potassium affinity and raising the extracellular sodium affinity compared to beta 1 and 3 (Larsen et al., 2014). This effect of beta on the pump was found to be due to the TM helix rather than the N- or Cterminal domains, and specifically to a difference between the three isoforms in the tilt angles of their TM helices (Hilbers et al., 2016).

The different beta isoforms and the variation in their post-translational modifications facilitate regulated $\mathrm{Na}, \mathrm{K}$-ATPase activity, adapted to different tissues and to environmental changes.

In mouse heart, the major beta isoform is beta1. Nonetheless, specific inactivation of its gene in cardiomyocytes results in a phenotype that appears healthy until approximately 10 months of age, and reduced contractility and enlarged hearts are only found after an additional 3-4 months (Barwe et al., 2009). Interestingly, heterozygous knock-out of alphal also results in reduced contractility, while heterozygous knockout of alpha2 results in hyper contractility (James et al., 1999); the alpha2 phenotype may, however, be a secondary effect of alpha2 deficiency in the brain (Rindler et al., 2013). Beta2 knock-out mice succumb at day 17-18 after birth, possibly due to dysfunction of vitally important brain structures (Magyar et al., 1994). There are currently no confirmed human 
TABLE 1 | Protein expression in tissues from the indicated mammals detected by western blots (WB) or immunostaining (IS) of Na,K-ATPase alpha1 (a1), alpha2 (a2), alpha3 (a3), alpha4(a4), beta1(b1), beta2(b2), beta3(b3), and FXYD(g). Cultured cells not included.

\begin{tabular}{|c|c|c|c|c|c|c|c|}
\hline Organ/part & Tissue/structure & Cell/tubule type & $\begin{array}{l}\text { Protein } \\
\text { found }\end{array}$ & $\begin{array}{l}\text { Protein } \\
\text { probed for }\end{array}$ & Organism & Method & References \\
\hline Brain & Microvessels & & $\begin{array}{l}\text { a1, a2, a3, } \\
\text { b1, b2 }\end{array}$ & $\begin{array}{l}a 1, a 2, a 3 \\
b 1, b 2\end{array}$ & rat & WB & Zlokovic et al., 1993 \\
\hline Brain & Choroid plexus & & $a 1, b 1, b 2$ & $\begin{array}{l}\text { a1, a2, a3, } \\
\text { b1, b2 }\end{array}$ & rat & WB & Zlokovic et al., 1993 \\
\hline Brain & $\begin{array}{l}\text { Several areas are } \\
\text { extensively studied }\end{array}$ & Only neurons & a3 & a3 & mouse & IS & Bottger et al., 2011 \\
\hline Brain & & & & a4 & human & WB & Hlivko et al., 2006 \\
\hline Brain & $\begin{array}{l}\text { Several areas are } \\
\text { studied }\end{array}$ & Neurons and Astrocytes & b1, b2 & b1, b2 & rat & WB, IS & Lecuona et al., 1996 \\
\hline Brain & Cerebral cortex & Astroglia & a2 & a2 & rat & IS & Cholet et al., 2002 \\
\hline Brain & $\begin{array}{l}\text { Axolemma, cerebrum, } \\
\text { cerebellum, corpus } \\
\text { callosum, optic nerve }\end{array}$ & & $a 1, a 2, a 3$ & a1, a2, a3 & rat & WB & Urayama et al., 1989 \\
\hline Brain & Microsomes & & b3 & b3 & rat & WB & $\begin{array}{l}\text { Arystarkhova and } \\
\text { Sweadner, } 1997\end{array}$ \\
\hline Colon & $\begin{array}{l}\text { Mucosae, } \\
\text { submucosae }\end{array}$ & Epithelial cells, mesenchymal cells & $\begin{array}{l}\text { a1, a3, b1, } \\
\text { b2 }\end{array}$ & $\begin{array}{l}\text { a1, a3, b1, } \\
\text { b2 }\end{array}$ & human & IS & $\begin{array}{l}\text { Baker Bechmann et al., } \\
2016\end{array}$ \\
\hline Colon & Myenteric plexus & Neurons & $\begin{array}{l}\text { (a1), a3, b1, } \\
\text { (b2) }\end{array}$ & $\begin{array}{l}\text { a1, a3, b1, } \\
\text { b2 }\end{array}$ & human & IS & $\begin{array}{l}\text { Baker Bechmann et al., } \\
2016\end{array}$ \\
\hline Colon & Myenteric plexus & Glia cells & $\begin{array}{l}\text { (a1), (a3), } \\
\text { b1, b2 }\end{array}$ & $\begin{array}{l}\text { a1, a3, b1, } \\
\text { b2 }\end{array}$ & human & IS & $\begin{array}{l}\text { Baker Bechmann et al., } \\
2016\end{array}$ \\
\hline Colon & Muscularis propia & Smooth muscle cells & (a1), a3, b2 & $\begin{array}{l}\text { a1, a3, b1, } \\
\text { b2 }\end{array}$ & human & IS & $\begin{array}{l}\text { Baker Bechmann et al., } \\
2016\end{array}$ \\
\hline Erythrocytes & & & $\begin{array}{l}\text { a1, a3, b1, } \\
\text { b2, b3 }\end{array}$ & $\begin{array}{l}\text { a1, a2, a3, } \\
\text { b1, b2, b3 }\end{array}$ & human & WB & Hoffman et al., 2002 \\
\hline Eye & Pars plicata & Nonpigmented epithelium & $\mathrm{a} 1, \mathrm{a} 2, \mathrm{a} 3$ & a1, a2, a3 & bovine & IS & Ghosh et al., 1990 \\
\hline Eye & Pars plicata & Pigmented epithelium & a1 & a1, a2, a3 & bovine & IS & Ghosh et al., 1990 \\
\hline Eye & Pars plana & Nonpigmented epithelium & $\mathrm{a} 1, \mathrm{a} 2$ & $\mathrm{a1}, \mathrm{a} 2, \mathrm{a3}$ & bovine & IS & Ghosh et al., 1990 \\
\hline Eye & Pars plana & Pigmented epithelium & a1 & $\mathrm{a1}, \mathrm{a} 2, \mathrm{a3}$ & bovine & IS & Ghosh et al., 1990 \\
\hline Eye & Retina & Photoreceptors & a3, b2, b3 & $\begin{array}{l}\text { a1, a2, a3, } \\
\text { b1, b2, b3 }\end{array}$ & mouse & IS & Wetzel et al., 1999 \\
\hline Eye & Retina & Horizontal cells & $\mathrm{a} 1, \mathrm{a} 3, \mathrm{~b} 1$ & $\begin{array}{l}\text { a1, a2, a3, } \\
\text { b1, b2, b3 }\end{array}$ & mouse & IS & Wetzel et al., 1999 \\
\hline Eye & Retina & Bipolar cells & a3, b2 & $\begin{array}{l}a 1, a 2, a 3 \\
b 1, b 2, b 3\end{array}$ & mouse & IS & Wetzel et al., 1999 \\
\hline Eye & Retina & Ganglion cells & $\begin{array}{l}\text { a1, a3, b1, } \\
\text { b2 }\end{array}$ & $\begin{array}{l}\text { a1, a2, a3, } \\
\text { b1, b2, b3 }\end{array}$ & mouse & IS & Wetzel et al., 1999 \\
\hline Eye & Retina & Amacrine cells & a3, b1 & $\begin{array}{l}a 1, a 2, a 3 \\
b 1, b 2, b 3\end{array}$ & mouse & IS & Wetzel et al., 1999 \\
\hline Eye & Retina & Müller cells & $\mathrm{a} 1, \mathrm{a} 2, \mathrm{~b} 2$ & $\begin{array}{l}\text { a1, a2, a3, } \\
\text { b1, b2, b3 }\end{array}$ & mouse & IS & Wetzel et al., 1999 \\
\hline Eye & Retina & Pigmented epithelium & $a 1, b 1$ & $\begin{array}{l}\text { a1, a2, a3, } \\
\text { b1, b2, b3 }\end{array}$ & mouse & IS & Wetzel et al., 1999 \\
\hline Heart & $\begin{array}{l}\text { Ventricular } \\
\text { myocardium }\end{array}$ & & a1, a2 & $\mathrm{a1}, \mathrm{a} 2, \mathrm{a3}$ & rat & WB & Sweadner et al., 1994 \\
\hline Heart & $\begin{array}{l}\text { Ventricular } \\
\text { myocardium }\end{array}$ & & $a 1, a 2, a 3$ & $\mathrm{a1}, \mathrm{a} 2, \mathrm{a3}$ & human & WB & Sweadner et al., 1994 \\
\hline Heart & $\begin{array}{l}\text { Left ventricle, right } \\
\text { ventricle, atrium, } \\
\text { ventricular septum, } \\
\text { papillary muscle, aorta }\end{array}$ & & a1, a3 & a1, a2, a3 & macaque & WB & Sweadner et al., 1994 \\
\hline Heart & & Cardiomyocytes & $\begin{array}{l}\text { a1, a2, b1, } \\
\text { b2, b3 }\end{array}$ & $\begin{array}{l}\text { a1, a2, b1, } \\
\text { b2, b3 }\end{array}$ & mouse/rat & WB, IS & Habeck et al., 2016 \\
\hline
\end{tabular}


TABLE 1 | Continued

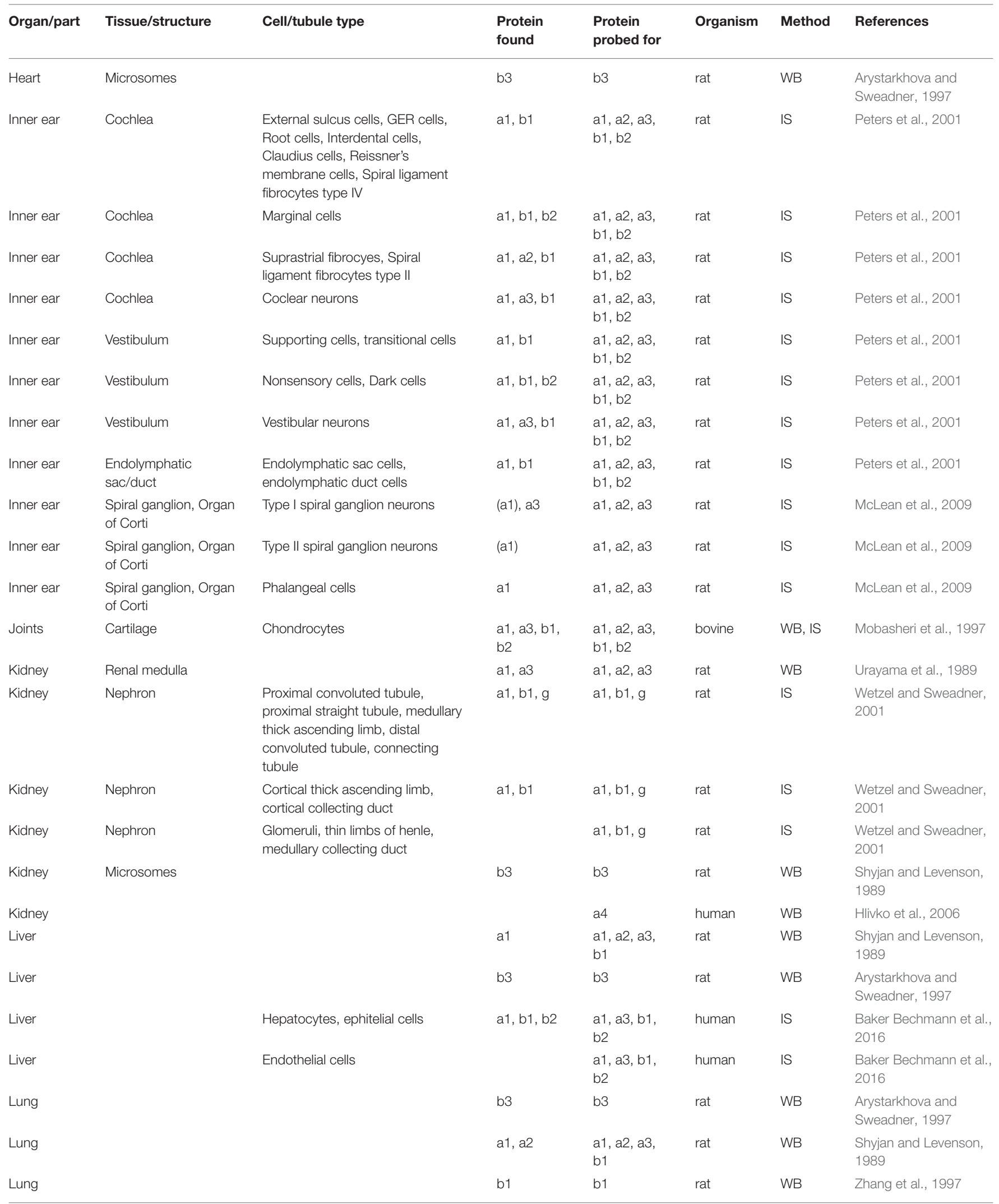


TABLE 1 | Continued

\begin{tabular}{|c|c|c|c|c|c|c|c|}
\hline Organ/part & Tissue/structure & Cell/tubule type & $\begin{array}{l}\text { Protein } \\
\text { found }\end{array}$ & $\begin{array}{l}\text { Protein } \\
\text { probed for }\end{array}$ & Organism & Method & References \\
\hline Placenta & & & $a 1, a 2, a 3$ & a1, a2, a3 & human & WB & Esplin et al., 2003 \\
\hline Prostate & & Epithelial cells & $\begin{array}{l}\text { a1, b1, b2, } \\
\text { b3 }\end{array}$ & $\begin{array}{l}a 1, a 2, a 3, \\
b 1, b 2, b 3, g\end{array}$ & rat & IS & Mobasheri et al., 2003 \\
\hline Prostate & & Smooth muscle, stroma & $\begin{array}{l}\text { a1, a2, b1, } \\
\text { b2 }\end{array}$ & $\begin{array}{l}\text { a1, a2, a3, } \\
\text { b1, b2, b3, g }\end{array}$ & rat & IS & Mobasheri et al., 2003 \\
\hline $\begin{array}{l}\text { Skeletal } \\
\text { muscle }\end{array}$ & $\begin{array}{l}\text { Extensor digitorum } \\
\text { longus }\end{array}$ & & $\begin{array}{l}\text { a1, a2, b1, } \\
\text { b2, b3 }\end{array}$ & $\begin{array}{l}a 1, a 2, a 3 \\
b 1, b 2, b 3\end{array}$ & mouse & WB & He et al., 2001 \\
\hline Spleen & Microsomes & & a1 & $a 1, a 2, a 3, b$ & rat & WB & $\begin{array}{l}\text { Shyjan and Levenson, } \\
1989\end{array}$ \\
\hline Testis & & Sperm & a1, a4 & a1, a4 & rat & IS & Blanco et al., 2000 \\
\hline Testis & & Sperm & a4 & a4 & human & WB, IS & Hlivko et al., 2006 \\
\hline Testis & & Sperm & a4 & a4 & bovine & WB, IS & Newton et al., 2009 \\
\hline Testis & & Sperm & a1, a4 & a1, a4 & mouse & WB & Jimenez et al., 2011a \\
\hline Testis & Microsomes & & b3 & b3 & rat & WB & $\begin{array}{l}\text { Arystarkhova and } \\
\text { Sweadner, } 1997\end{array}$ \\
\hline Uterus & & Epithelial cells, smooth muscle cells & $\begin{array}{l}a 1, a 2,(a 3) \\
b 1, b 2,(b 3) \\
g\end{array}$ & $\begin{array}{l}a 1, a 2, a 3, \\
b 1, b 2, b 3, g\end{array}$ & human & IS & Floyd et al., 2010 \\
\hline
\end{tabular}

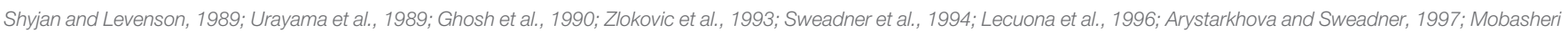

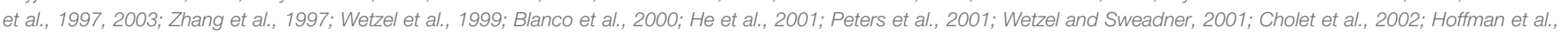

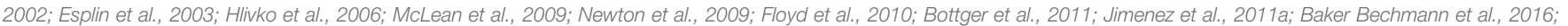
Habeck et al., 2016.

genetic diseases linked with mutations in any of the beta subunits.

\section{FXYDs}

The minimal functional unit of the Na,K-ATPase has an alpha and a beta subunit, but it can be further modified by a third subunit, the FXYD, named after a shared PFxYD motif in the Nterminal, extracellular part of the single TM protein. Mammals express seven FXYD proteins, most of which appear to lower the substrate affinities or Vmax of the pump, though they may also serve functions in addition to modulating Na,K-ATPase function (Geering, 2005).

FXYD1 is highly expressed in the heart, skeletal muscle and brain. Two serines in the intracellular part can be phosporylated by protein kinases $\mathrm{A}$ and $\mathrm{C}$, and its alternative name, phospholemman, reflects that it was originally described as a highly phosphorylated ( $15-45 \%)$ heart protein (Palmer et al., 1991; Walaas et al., 1994; Cheung et al., 2010). Phosphorylation decreases the inhibitory effect of FXYD1 (Cheung et al., 2010; Mishra et al., 2015), and mouse knock-out of the subunit increases Na,K-ATPase activity in the heart (Jia et al., 2005; Bell et al., 2008).

FXYD2, or gamma, was the first FXYD found to be associated with the Na,K-ATPase (Forbush et al., 1978). It is highly expressed in the kidney, and like FXYD1, lowers pump activity, an inhibition that is also relieved if the protein is knocked out in mice (Jones et al., 2005; Arystarkhova, 2016). Mice lacking FXYD2 are viable, but have impaired reproduction, possibly because of a metabolic phenotype where glucose is highly tolerated (Arystarkhova et al., 2013). In the collecting duct of the kidney, FXYD4 is expressed, which, unlike most FXYDs, increases the pump's sodium affinity and thus enhances activity (Geering, 2005).

The roles of FXYD3 (Mat-8) and FXYD5 (dysadherin) are unclear, but they appear to be overexpressed in some cancer cells (Arimochi et al., 2007; Nam et al., 2007), and FXYD6 and 7 are expressed in the brain (Geering, 2005). There are currently no confirmed human genetic diseases linked with mutations in FXYD subunits.

\section{DISEASE-CAUSING MUTATIONS IN Na,K-ATPASE ALPHA ISOFORMS \\ Alpha1 in Disease}

Deleterious mutations in ATP1A1 are unlikely to be compatible with life, but in a subset of aldosterone producing adenomas (APAs) in the adrenal gland, somatic mutations in ATP1A1 can contribute to the altered hormone balance (Azizan et al., 2013; Beuschlein et al., 2013). Adrenal overproduction of aldosterone is the cause of hypertension in up to $10 \%$ of hypertensive patients, and if adrenal adenomas are identified and removed, the patients will typically be cured.

The normal signal pathway is that adrenal cells respond to the peptide hormone angiotensin II and to extracellular potassium by depolarization and opening of voltage-gated calcium channels, and the rise in cytoplasmic calcium levels stimulates expression of the aldosterone synthase. The dependence on extracellular stimuli can, however, be circumvented if the downstream signals are directly induced by mutations in the systems that normally 
control membrane potential and calcium levels, including a potassium channel (KCNJ5, Choi et al., 2011), a calcium channel (CACNA1D, Azizan et al., 2013), and a calcium pump (ATP2B3, Beuschlein et al., 2013). Most recently, a link was found between APAs and mutations causing beta-catenin (CTNNB1) to excessively activate the Wnt-signaling pathway that normally controls adrenocortical development (Teo et al., 2015). Even in adrenal glands with hyperplasia but no adenoma, somatic mutations in CACNA1D (Scholl et al., 2015) and ATP1A1 (Nishimoto et al., 2015) have been found.

The coupling of ATP1A1 mutations to hypertension does not immediately make as much sense as for the potassium channel and calcium regulators. Why would a single non-functional copy of the gene have such marked effect on aldosterone production? One clue was that there is a prominent hotspot for mutation in TM1 next to the ion coordinating Glu327 in TM4, especially Leu104Arg is commonly found in APAs, and another reoccurring spot for alterations is in TM4 right next to Glu327 (Figure 1, Kopec et al., 2014). A third hotspot is in TM9, where deletions close to site III, the sodium-specific site, are found (Figure 2). Expression of the mutant forms of the pump cause depolarization (Beuschlein et al., 2013; Stindl et al., 2015), and expression studies in Xenopus oocytes show that the mutations all cause similar gain-of-function, namely that instead of being an ion pump, the mutations in ATP1A1 make the Na,K-ATPases into ion channels that allow sodium or protons (depending on the specific mutation) to flow into the cell. Potassium is not (or for the TM9 deletions, only to a minor extend) transported, and physiological potassium levels have negligible effect (Azizan et al., 2013).

The effect of turning a pump into a channel is much more severe than simply inactivating the pump. The ATP1A1 mutations clearly show this-only regions where mutations cause the pump to become a cation channel have been reported in APAs, while many of the disease-causing mutations in ATP1A2 and ATP1A3 seem to impair pump function (cf. below). Pharmacologically, the same is evident-pump inhibitors like cardiotonic steroids are toxic, but not nearly as toxic as a huge molecule produced in Palythoa corals, palytoxin, which binds the sodium pump and turns it into a channel by causing the inner and outer gates to open simultaneously. Palytoxin is the second deadliest non-peptide molecule known, since just a single molecule on a cell surface can dissipate the cell's ionic gradient (Rossini and Bigiani, 2011).

\section{Alpha2 in Disease}

Familial Hemiplegic Migraine (FHM) is an autosomally inherited form of migraine where the patients experience aura and weakness in one side of the body during attacks. FHM-causing mutations have been identified in three genes encoding a calcium channel (FHM1), a sodium channel (FHM3) and the alpha2 subunit (FHM2) (De Fusco et al., 2003). At least 80 mutations in ATP1A2 have been described to cause FHM2 (Figure 4, reviewed in Bottger et al., 2012; Pelzer et al., 2016). In contrast to the ATP1A1 mutations that all target recurrent hotspots, many of the mutations in ATP1A2 have been reported just once, and they affect both the transmembrane and the cytoplasmic parts of the protein. Most of the mutations that have been characterized cause loss or reduction of function, either because the ATPase function of the pump is compromised or because ion binding and transport are affected, but many of the mutations also impair trafficking of the pump to the membrane (Morth et al., 2009'Spiller and Friedrich, 2014).

The Na,K-ATPase in astrocytes with alpha2 and the beta2 subunit has relatively low potassium affinity and is suggested to be particularly important when the extracellular potassium concentration is high (Larsen et al., 2014). In agreement with this suggestion, mouse models with FHM2 mutations knocked in show reduced clearance of potassium and glutamate (Bottger et al., 2016; Capuani et al., 2016). Elevated potassium and glutamate levels are known to augment cortical spreading depression, which is suggested to cause some of the symptoms experienced by patients having an attack of migraine with aura, and enhanced spreading depression was measured in the knockin mice (Lauritzen et al., 2011). Cortical spreading depression is characterized by a wave of lack of neuronal activity that travels across the cerebral gray matter after a brief period of hyperexcitability. Normally, astrocytes protect against cortical spreading depression because they take up potassium and glutamate (Lauritzen et al., 2011), but when there is a high need for restoring of the ionic gradients and only one allele from which a fully functional alpha2 can be expressed, the astrocyte may not be able to fulfill that role to satisfaction: the Na,K-ATPase is both directly involved in potassium clearing and indirectly in glutamate clearing, because the glutamate transporter uses the energy from co-transport of three sodium ions and countertransport of one potassium ion to transport one molecule of glutamate.

\section{Alpha3 in Disease}

Autosomal dominant mutations in ATP1A3 were first shown to cause Rapid-onset Dystonia Parkinsonism (RDP, de Carvalho Aguiar et al., 2004), and later two other neurological syndromes, Alternating Hemiplegia of Childhood (AHC, Heinzen et al., 2012; Rosewich et al., 2012) and CAPOS (cerebellar ataxia, areflexia, pes cavus, optic atrophy, and sensorineural hearing loss, Demos et al., 2014). Although the three syndromes were originally identified as phenotypically distinct, it has become clear that many patients do not strictly fall into one category or the other, but may have symptoms that fall on a continuous spectrum as well as unique symptoms for individual mutations (Rosewich et al., 2014; Paciorkowski et al., 2015; Sweney et al., 2015; Kanemasa et al., 2016; Liu et al., 2016; Smedemark-Margulies et al., 2016; Sweadner et al., 2016).

RDP is characterized by a triggering, stressful event causing sudden (hours to days) onset of irreversible rostrocaudal gradient of dystonia with parkinsonism. The onset is typically caused by physical or emotional stress in early adulthood, and in addition to the motor effects, most patients have psychiatric symptoms (Brashear et al., 2012). The patients are unresponsive to L-DOPA, and there is no drug therapy available.

AHC patients are typically diagnosed before 18 months of age from recurring episodes of weakness or paralysis of one side of the body. The attacks can vary in length from 


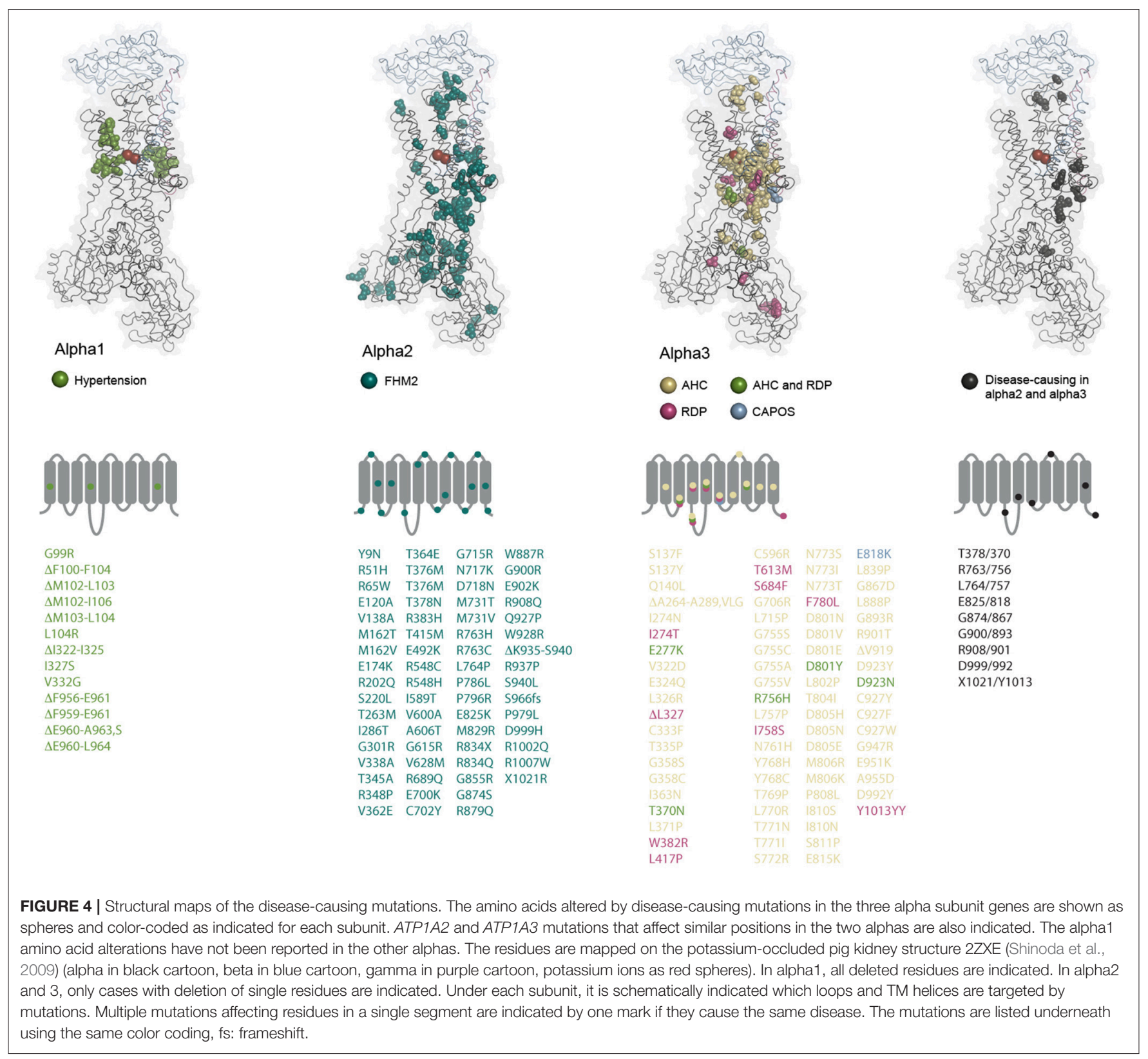

minutes to days and are typically combined with additional paroxysmal symptoms like dystonia, choreoathetosis, nystagmus and about half of the patients have epileptic seizures. During sleep, symptoms disappear (Heinzen et al., 2014). AHC is further associated with progressive deterioration of the patient's health between attacks, including developmental delay, retardation, hypotonia and compromised motor skills. For treatment, the calcium channel blocker flunarizine may reduce the length and severity of attacks in some patients, and benzodiazipines may have positive effect, possibly because they induce sleep. A ketonic diet has also been reported to stall disease progression (Roubergue et al., 2015).

CAPOS syndrome typically starts in childhood when fever triggers the disease, which is characterized by cerebellar ataxia, areflexia, and progressive loss of sight and hearing. Nystagmus and hypotonia are also common symptoms (Heimer et al., 2015).

For all of the three diseases, it is clear that the ATP1A3 mutations have high penetrance, but also that the genetic background of an affected individual is important for its manifestations. Because of the severity of RDP and AHC, the mutations are typically de novo, while CAPOS is also inherited.

There are now close to 80 different disease-associated mutations reported in ATP1A3 (Figure 4). At some positions, amino acid changes cause RDP as well as AHC, but most of the mutations are unique for one of the diseases, and there are genotype-phenotype correlations: all CAPOS patients sequenced have the same, single mutation, E818K, and all people identified with the mutation have CAPOS. For AHC and RDP, ATP1A3 
mutations have been found in most but not all of the sequenced patients, so it remains to be determined if mutations in other genes can give similar symptoms. Strikingly, just two mutations, D801N and E815K, account for up to two thirds of the AHC patients, while the RDP-causing mutations seem to target the protein broadly with no obvious hotspots (Figure 4). Compared to the disease-causing mutations in ATP1A1 and ATP1A2, RDP is in that respect more similar to FHM2 where many of the mutations may be associated with loss-of-function, while few hotspot positions give the phenotypes in AHC and CAPOS, as also seen for hypertension-causing ATP1A1 mutations. It remains to be determined whether alpha3 gains any novel functions in AHC or CAPOS patients, but it has been suggested that the AHC-causing mutations may exert a dominant negative effect on the alpha3 expressed from the healthy allele by an unknown mechanism (Li et al., 2015).

Markedly, none of the mutations that change alphal from a pump to a channel have been described for the other genes, probably because that would be too severe an alteration. A few of the mutations in ATP1A2 and ATP1A3 target the same positions (Figure 4), but it is clear from the structural mapping that the ATP1A3 mutations often target the ion binding sites, while that is not the case for $A T P 1 A 2$, possibly suggesting that impaired ion binding in alpha 2 would be incompatible with life or that they cause other symptoms than FHM.

\section{CONCLUSION}

The Na,K-ATPase was first described 60 years ago by Jens Christian Skou (Skou, 1957), but novel insight into the pump's atomic structure, cellular regulation and pathophysiological roles

\section{REFERENCES}

Alevizopoulos, K., Calogeropoulou, T., Lang, F., and Stournaras, C. (2014). $\mathrm{Na}^{+} / \mathrm{K}^{+}$ATPase inhibitors in cancer. Curr. Drug Targets 15, 988-1000. doi: 10.2174/1389450115666140908125025

Antonicek, H., Persohn, E., and Schachner, M. (1987). Biochemical and functional characterization of a novel neuron-glia adhesion molecule that is involved in neuronal migration. J. Cell Biol. 104, 1587-1595. doi: 10.1083/jcb.104. 6.1587

Aperia, A., Akkuratov, E. E., Fontana, J. M., and Brismar, H. (2016). $\mathrm{Na}^{+}-\mathrm{K}^{+}$ATPase, a new class of plasma membrane receptors. Am. J. Physiol. Cell Physiol. 310, C491-C495. doi: 10.1152/ajpcell.00359.2015

Arimochi, J., Ohashi-Kobayashi, A., and Maeda, M. (2007). Interaction of Mat-8 (FXYD-3) with $\mathrm{Na}^{+} / \mathrm{K}^{+}$-ATPase in colorectal cancer cells. Biol. Pharm. Bull. 30, 648-654. doi: 10.1248/bpb.30.648

Arystarkhova, E. (2016). Beneficial renal and pancreatic phenotypes in a mouse deficient in FXYD2 regulatory subunit of Na,K-ATPase. Front. Physiol. 7:88. doi: 10.3389/fphys.2016.00088

Arystarkhova, E., Liu, Y. B., Salazar, C., Stanojevic, V., Clifford, R. J., Kaplan, J. H., et al. (2013). Hyperplasia of pancreatic $\beta$ cells and improved glucose tolerance in mice deficient in the FXYD2 subunit of Na,K-ATPase. J. Biol. Chem. 288, 7077-7085. doi: 10.1074/jbc.M112.401190

Arystarkhova, E., and Sweadner, K. J. (1997). Tissue-specific expression of the $\mathrm{Na}, \mathrm{K}$-ATPase $\beta 3$ subunit. The presence of $\beta 3$ in lung and liver addresses the problem of the missing subunit. J. Biol. Chem. 272, 22405-22408. doi: $10.1074 / j b c .272 .36 .22405$ continues to emerge, and many aspects await future studies. The various subunit isoforms are optimized for the specific requirements and challenges that different cell types face for maintaining ionic homeostasis: the subunit variation allows for fine-tuning of the basic kinetic properties of the pump as elucidated in many studies, but much remains to be learned about how the variation determines interactions with other cellular partners and thereby regulates e.g., the activity, localization and stability of the pump. Furthermore, the amazingly improved possibilities for sequencing patient DNA will likely disclose novel links between mutations affecting alpha subunits and pathophysiological conditions: Adenomas other than the adrenal may gain advantage from somatic mutations affecting the alphal subunit, and mutations altering e.g., the ion binding residues in alpha2 may confer diseases other than FHM2. It is also still enigmatic why the different mutations in the alpha3 gene cause such varied diseases, and since alpha4 is essential for sperm function, mutations in its gene are highly likely to affect the male bearers' fertility. It further remains to be determined whether mutations in the beta or FXYD subunit genes are associated with diseases.

\section{AUTHOR CONTRIBUTIONS}

$\mathrm{MC}, \mathrm{FH}$, and HP discussed, wrote and edited the manuscript and made the tables and figures.

\section{FUNDING}

$\mathrm{HP}$ and FH were funded by the Lundbeck Foundation. MC was funded by AIAS, AU.

Arystarkhova, E., and Sweadner, K. J. (2016). Functional studies of $\mathrm{Na}\left({ }^{+}\right), \mathrm{K}\left(^{+}\right)$ATPase using transfected cell cultures. Methods Mol. Biol. 1377, 321-332. doi: 10.1007/978-1-4939-3179-8_28

Attwell, D., and Laughlin, S. B. (2001). An energy budget for signaling in the grey matter of the brain. J. Cereb. Blood Flow Metab. 21, 1133-1145. doi: 10.1097/00004647-200110000-00001

Azarias, G., Kruusmagi, M., Connor, S., Akkuratov, E. E., Liu, X. L., Lyons, D., et al. (2013). A specific and essential role for Na,K-ATPase $\alpha 3$ in neurons co-expressing $\alpha 1$ and $\alpha 3$. J. Biol. Chem. 288, 2734-2743. doi: 10.1074/jbc.M112.425785

Azizan, E. A., Poulsen, H., Tuluc, P., Zhou, J., Clausen, M. V., Lieb, A., et al. (2013). Somatic mutations in ATP1A1 and CACNA1D underlie a common subtype of adrenal hypertension. Nat. Genet. 45, 1055-1060. doi: 10.1038/ ng.2716

Baker Bechmann, M., Rotoli, D., Morales, M., Maeso Mdel, C., Garcia Mdel, P., Avila, J., et al. (2016). Na,K-ATPase isozymes in colorectal cancer and liver metastases. Front. Physiol. 7:9. doi: 10.3389/fphys.2016. 00009

Barwe, S. P., Jordan, M. C., Skay, A., Inge, L., Rajasekaran, S. A., Wolle, D., et al. (2009). Dysfunction of ouabain-induced cardiac contractility in mice with heart-specific ablation of Na,K-ATPase $\beta 1$-subunit. J. Mol. Cell. Cardiol. 47, 552-560. doi: 10.1016/j.yjmcc.2009.07.018

Bell, J. R., Kennington, E., Fuller, W., Dighe, K., Donoghue, P., Clark, J. E., et al. (2008). Characterization of the phospholemman knockout mouse heart: depressed left ventricular function with increased Na-K-ATPase activity. Am. J. Physiol. Heart Circ. Physiol. 294, H613-H621. doi: 10.1152/ajpheart.01332.2007 
Beuschlein, F., Boulkroun, S., Osswald, A., Wieland, T., Nielsen, H. N., Lichtenauer, U. D., et al. (2013). Somatic mutations in ATP1A1 and ATP2B3 lead to aldosterone-producing adenomas and secondary hypertension. Nat. Genet. 45 , 440-444, 444e1-2. doi: 10.1038/ng.2550

Blanco, G. (2005). Na,K-ATPase subunit heterogeneity as a mechanism for tissue-specific ion regulation. Semin. Nephrol. 25, 292-303. doi: 10.1016/j.semnephrol.2005.03.004

Blanco, G., Melton, R. J., Sanchez, G., and Mercer, R. W. (1999). Functional characterization of a testes-specific $\alpha$-subunit isoform of the sodium/potassium adenosinetriphosphatase. Biochemistry 38, 13661-13669. doi: $10.1021 / \mathrm{bi} 991207 \mathrm{~b}$

Blanco, G., and Mercer, R. W. (1998). Isozymes of the Na-K-ATPase: heterogeneity in structure, diversity in function. Am. J. Physiol. 275, F633-F650.

Blanco, G., Sanchez, G., Melton, R. J., Tourtellotte, W. G., and Mercer, R. W. (2000). The $\alpha 4$ isoform of the $\mathrm{Na}, \mathrm{K}-\mathrm{ATPa} e$ is expressed in the germ cells of the testes. J. Histochem. Cytochem. 48, 1023-1032. doi: $10.1177 / 002215540004800801$

Blom, H., Bernhem, K., and Brismar, H. (2016). Sodium pump organization in dendritic spines. Neurophotonics 3:041803. doi: 10.1117/1.NPh.3.4.041803

Borlak, J., and Thum, T. (2003). Hallmarks of ion channel gene expression in end-stage heart failure. FASEB J. 17, 1592-1608. doi: 10.1096/fj.02-0889com

Bottger, P., Doganli, C., and Lykke-Hartmann, K. (2012). Migraine- and dystoniarelated disease-mutations of $\mathrm{Na}^{+} / \mathrm{K}^{+}$-ATPases: relevance of behavioral studies in mice to disease symptoms and neurological manifestations in humans. Neurosci. Biobehav. Rev. 36, 855-871. doi: 10.1016/j.neubiorev.2011.10.005

Bottger, P., Glerup, S., Gesslein, B., Illarionova, N. B., Isaksen, T. J., Heuck, A., et al. (2016). Glutamate-system defects behind psychiatric manifestations in a familial hemiplegic migraine type 2 disease-mutation mouse model. EMBO Mol. Med. 6:22047. doi: 10.1038/srep22047

Bottger, P., Tracz, Z., Heuck, A., Nissen, P., Romero-Ramos, M., and Lykke-Hartmann, K. (2011). Distribution of Na/K-ATPase $\alpha 3$ isoform, a sodium-potassium P-type pump associated with rapid-onset of dystonia parkinsonism (RDP) in the adult mouse brain. J. Comp. Neurol. 519, 376-404. doi: $10.1002 / \mathrm{cne} .22524$

Brashear, A., Cook, J. F., Hill, D. F., Amponsah, A., Snively, B. M., Light, L., et al. (2012). Psychiatric disorders in rapid-onset dystonia-parkinsonism. Neurology 79, 1168-1173. doi: 10.1212/WNL.0b013e3182698d6c

Brown, P. D., Davies, S. L., Speake, T., and Millar, I. D. (2004). Molecular mechanisms of cerebrospinal fluid production. Neuroscience 129, 957-970. doi: 10.1016/j.neuroscience.2004.07.003

Caplan, M. J., Anderson, H. C., Palade, G. E., and Jamieson, J. D. (1986). Intracellular sorting and polarized cell surface delivery of $\left(\mathrm{Na}^{+}, \mathrm{K}^{+}\right)$ATPase, an endogenous component of MDCK cell basolateral plasma membranes. Cell 46, 623-631. doi: 10.1016/0092-8674(86)90888-3

Capuani, C., Melone, M., Tottene, A., Bragina, L., Crivellaro, G., and Santello, M. (2016). Defective glutamate and $\mathrm{K}^{+}$clearance by cortical astrocytes in familial hemiplegic migraine type 2. 8, 967-986. doi: 10.15252/emmm.201505944

Cheung, J. Y., Zhang, X. Q., Song, J., Gao, E., Rabinowitz, J. E., Chan, T. O., et al. (2010). Phospholemman: a novel cardiac stress protein. Clin. Transl. Sci. 3, 189-196. doi: 10.1111/j.1752-8062.2010.00213.x

Choi, M., Scholl, U. I., Yue, P., Bjorklund, P., Zhao, B., Nelson-Williams, C., et al. (2011). $\mathrm{K}^{+}$channel mutations in adrenal aldosterone-producing adenomas and hereditary hypertension. Science 331, 768-772. doi: 10.1126/science.1198785

Cholet, N., Pellerin, L., Magistretti, P. J., and Hamel, E. (2002). Similar perisynaptic glial localization for the $\mathrm{Na}^{+}, \mathrm{K}^{+}$-ATPase $\alpha 2$ subunit and the glutamate transporters GLAST and GLT-1 in the rat somatosensory cortex. Cereb. Cortex 12, 515-525. doi: 10.1093/cercor/12.5.515

Clausen, M. J., Nissen, P., and Poulsen, H. (2011). The pumps that fuel a sperm's journey. Biochem. Soc. Trans. 39, 741-745. doi: 10.1042/BST0390741

Clausen, M. V., Nissen, P., and Poulsen, H. (2016). The $\alpha 4$ isoform of the $\mathrm{Na}\left({ }^{+}\right), \mathrm{K}\left({ }^{+}\right)$-ATPase is tuned for changing extracellular environments. FEBS J. 283, 282-293. doi: 10.1111/febs.13567

Crambert, G., Hasler, U., Beggah, A. T., Yu, C., Modyanov, N. N., Horisberger, J. D., et al. (2000). Transport and pharmacological properties of nine different human Na, K-ATPase isozymes. J. Biol. Chem. 275, 1976-1986. doi: 10.1074/jbc.275.3.1976

de Carvalho Aguiar, P., Sweadner, K. J., Penniston, J. T., Zaremba, J., Liu, L., Caton, M., et al. (2004). Mutations in the $\mathrm{Na}^{+} / \mathrm{K}^{+}$-ATPase $\alpha 3$ gene ATP1A3 are associated with rapid-onset dystonia parkinsonism. Neuron 43, 169-175. doi: 10.1016/j.neuron.2004.06.028

De Fusco, M., Marconi, R., Silvestri, L., Atorino, L., Rampoldi, L., Morgante, L., et al. (2003). Haploinsufficiency of ATP1A2 encoding the $\mathrm{Na}^{+} / \mathrm{K}^{+}$pump $\alpha 2$ subunit associated with familial hemiplegic migraine type 2. Nat. Genet. 33, 192-196. doi: 10.1038/ng1081

Demos, M. K., van Karnebeek, C. D., Ross, C. J., Adam, S., Shen, Y., Zhan, S. H., et al. (2014). A novel recurrent mutation in ATP1A3 causes CAPOS syndrome. Orphanet J. Rare Dis. 9:15. doi: 10.1186/1750-1172-9-15

Dorus, S., Wasbrough, E. R., Busby, J., Wilkin, E. C., and Karr, T. L. (2010). Sperm proteomics reveals intensified selection on mouse sperm membrane and acrosome genes. Mol. Biol. Evol. 27, 1235-1246. doi: 10.1093/molbev/msq007

Dostanic, I., Schultz Jel, J., Lorenz, J. N., and Lingrel, J. B. (2004). The $\alpha 1$ isoform of $\mathrm{Na}, \mathrm{K}-\mathrm{ATP}$ ase regulates cardiac contractility and functionally interacts and colocalizes with the Na/Ca exchanger in heart. J. Biol. Chem. 279, 54053-54061. doi: 10.1074/jbc.M410737200

Durlacher, C. T., Chow, K., Chen, X. W., He, Z. X., Zhang, X., Yang, T., et al. (2015). Targeting $\mathrm{Na}\left({ }^{+}\right) / \mathrm{K}\left({ }^{+}\right)$-translocating adenosine triphosphatase in cancer treatment. Clin. Exp. Pharmacol. Physiol. 42, 427-443. doi: $10.1111 / 1440-1681.12385$

El Mernissi, G., and Doucet, A. (1984). Quantitation of [3H] ouabain binding and turnover of Na-K-ATPase along the rabbit nephron. Am. J. Physiol. 247, F158-F167.

Esplin, M. S., Fausett, M. B., Faux, D. S., and Graves, S. W. (2003). Changes in the isoforms of the sodium pump in the placenta and myometrium of women in labor. Am. J. Obstet. Gynecol. 188, 759-764. doi: 10.1067/mob.2003.166

Floyd, R. V., Wray, S., Quenby, S., Martin-Vasallo, P., and Mobasheri, A. (2010). Expression and distribution of Na, K-ATPase isoforms in the human uterus. Reprod. Sci. 17, 366-376. doi: 10.1177/1933719109355196

Forbush, B. III., Kaplan, J. H., and Hoffman, J. F. (1978). Characterization of a new photoaffinity derivative of ouabain: labeling of the large polypeptide and of a proteolipid component of the Na, K-ATPase. Biochemistry 17, 3667-3676. doi: 10.1021/bi00610a037

Gaborit, N., Varro, A., Le Bouter, S., Szuts, V., Escande, D., Nattel, S., et al. (2010). Gender-related differences in ion-channel and transporter subunit expression in non-diseased human hearts. J. Mol. Cell. Cardiol. 49, 639-646. doi: 10.1016/j.yjmcc.2010.06.005

Gao, H., Popescu, R., Kopp, B., and Wang, Z. (2011). Bufadienolides and their antitumor activity. Nat. Prod. Rep. 28, 953-969. doi: 10.1039/c0np00032a

Garcia, A., Eljack, N. D., Sani, M. A., Separovic, F., Rasmussen, H. H., Kopec, W., et al. (2015). Membrane accessibility of glutathione. Biochim. Biophys. Acta 1848, 2430-2436. doi: 10.1016/j.bbamem.2015.07.016

Geering, K. (2005). Function of FXYD proteins, regulators of Na, K-ATPase. J. Bioenerg. Biomembr. 37, 387-392. doi: 10.1007/s10863-005-9476-x

Ghosh, S., Freitag, A. C., Martin-Vasallo, P., and Coca-Prados, M. (1990). Cellular distribution and differential gene expression of the three $\alpha$ subunit isoforms of the Na,K-ATPase in the ocular ciliary epithelium. J. Biol. Chem. 265, 2935-2940.

Gloor, S., Antonicek, H., Sweadner, K. J., Pagliusi, S., Frank, R., Moos, M., et al. (1990). The adhesion molecule on glia (AMOG) is a homologue of the $\beta$ subunit of the Na,K-ATPase. J. Cell Biol. 110, 165-174. doi: 10.1083/jcb.110.1.165

Gundersen, D., Orlowski, J., and Rodriguez-Boulan, E. (1991). Apical polarity of $\mathrm{Na}, \mathrm{K}$-ATPase in retinal pigment epithelium is linked to a reversal of the ankyrin-fodrin submembrane cytoskeleton. J. Cell Biol. 112, 863-872. doi: $10.1083 /$ jcb.112.5.863

Habeck, M., Tokhtaeva, E., Nadav, Y., Ben Zeev, E., Ferris, S. P., Kaufman, R. J., et al. (2016). Selective assembly of Na,K-ATPase $\alpha 2 \beta 2$ heterodimers in the heart: distinct functional properties and isoform-selective inhibitors. J. Biol. Chem. 291, 23159-23174. doi: 10.1074/jbc.M116.751735

He, S., Shelly, D. A., Moseley, A. E., James, P. F., James, J. H., Paul, R. J., et al. (2001). The $\alpha_{1}$ - and $\alpha_{2}$-isoforms of Na-K-ATPase play different roles in skeletal muscle contractility. Am. J. Physiol. Regul. Integr. Comp Physiol. 281, R917R925. Available online at: http://ajpregu.physiology.org/content/281/3/R917. long

Heimer, G., Sadaka, Y., Israelian, L., Feiglin, A., Ruggieri, A., Marshall, C. R., et al. (2015). CAOS-episodic cerebellar ataxia, areflexia, optic atrophy, and sensorineural hearing loss: a third allelic disorder of the ATP1A3 gene. J. Child Neurol. 30, 1749-1756. doi: 10.1177/0883073815579708 
Heinzen, E. L., Arzimanoglou, A., Brashear, A., Clapcote, S. J., Gurrieri, F., Goldstein, D. B., et al. (2014). Distinct neurological disorders with ATP1A3 mutations. Lancet Neurol. 13, 503-514. doi: 10.1016/S1474-4422(14)70011-0

Heinzen, E. L., Swoboda, K. J., Hitomi, Y., Gurrieri, F., Nicole, S., de Vries, B., et al. (2012). De novo mutations in ATP1A3 cause alternating hemiplegia of childhood. Nat. Genet. 44, 1030-1034. doi: 10.1038/ng.2358

Henriksen, C., Kjaer-Sorensen, K., Einholm, A. P., Madsen, L. B., Momeni, J., Bendixen, C., et al. (2013). Molecular cloning and characterization of porcine $\mathrm{Na}\left({ }^{+}\right) / \mathrm{K}\left({ }^{+}\right)$-ATPase isoforms $\alpha 1, \alpha 2, \alpha 3$ and the ATP1A3 promoter. PLoS ONE 8:e79127. doi: 10.1371/journal.pone.0079127

Hilbers, F., Kopec, W., Isaksen, T. J., Holm, T. H., Lykke-Hartmann, K., Nissen, P., et al. (2016). Tuning of the Na,K-ATPase by the $\beta$ subunit. Sci. Rep. 6:20442. doi: $10.1038 /$ srep20442

Hlivko, J. T., Chakraborty, S., Hlivko, T. J., Sengupta, A., and James, P. F. (2006), The human Na,K-ATPase $\alpha 4$ isoform is a ouabain-sensitive $\alpha$ isoform that is expressed in sperm. Mol. Reprod. Dev. 73, 101-115. doi: 10.1002/mrd.20383

Hoffman, J. F., Wickrema, A., Potapova, O., Milanick, M., and Yingst, D. R. (2002). Na pump isoforms in human erythroid progenitor cells and mature erythrocytes. Proc. Natl. Acad. Sci. U.S.A. 99, 14572-14577. doi: 10.1073/pnas.222539999

Horisberger, J. D., and Kharoubi-Hess, S. (2002). Functional differences between $\alpha$ subunit isoforms of the rat $\mathrm{Na}, \mathrm{K}$-ATPase expressed in Xenopus oocytes. J. Physiol. 539, 669-680. doi: 10.1113/jphysiol.2001.013201

James, P. F., Grupp, I. L., Grupp, G., Woo, A. L., Askew, G. R., Croyle, M. L., et al. (1999). Identification of a specific role for the Na,K-ATPase $\alpha$ 2 isoform as a regulator of calcium in the heart. Mol. Cell 3, 555-563. doi: 10.1016/S1097-2765(00)80349-4

Jia, L. G., Donnet, C., Bogaev, R. C., Blatt, R. J., McKinney, C. E., Day, K. H., et al. (2005). Hypertrophy, increased ejection fraction, and reduced Na-K-ATPase activity in phospholemman-deficient mice. Am. J. Physiol. Heart Circ. Physiol. 288, H1982-H1988. doi: 10.1152/ajpheart.00142.2004

Jimenez, T., McDermott, J. P., Sanchez, G., and Blanco, G. (2011a). Na,K-ATPase $\alpha 4$ isoform is essential for sperm fertility. Proc. Natl. Acad. Sci. U.S.A. 108, 644-649. doi: 10.1073/pnas.1016902108

Jimenez, T., Sanchez, G., and Blanco, G. (2012). Activity of the Na,K-ATPase $\alpha 4$ isoform is regulated during sperm capacitation to support sperm motility. J. Androl. 33, 1047-1057. doi: 10.2164/jandrol.111.015545

Jimenez, T., Sanchez, G., McDermott, J. P., Nguyen, A. N., Kumar, T. R., and Blanco, G. (2011b). Increased expression of the Na,K-ATPase $\alpha 4$ isoform enhances sperm motility in transgenic mice. Biol. Reprod. 84, 153-161. doi: 10.1095/biolreprod.110.087064

Jones, D. H., Li, T. Y., Arystarkhova, E., Barr, K. J., Wetzel, R. K., Peng, J., et al. (2005). Na,K-ATPase from mice lacking the $\gamma$ subunit (FXYD2) exhibits altered $\mathrm{Na}^{+}$affinity and decreased thermal stability. J. Biol. Chem. 280, 19003-19011. doi: 10.1074/jbc.M500697200

Juhaszova, M., and Blaustein, M. P. (1997). Distinct distribution of different $\mathrm{Na}^{+}$ pump $\alpha$ subunit isoforms in plasmalemma. Physiological implications. Ann. N.Y. Acad. Sci. 834, 524-536. doi: 10.1111/j.1749-6632.1997.tb52310.x

Kanai, R., Ogawa, H., Vilsen, B., Cornelius, F., and Toyoshima, C. (2013). Crystal structure of a $\mathrm{Na}^{+}$-bound $\mathrm{Na}^{+}, \mathrm{K}^{+}$-ATPase preceding the E1P state. Nature 502, 201-206. doi: 10.1038/nature12578

Kanemasa H, Fukai R, Sakai Y, Torio M, Miyake N, Lee S (2016). De novo p.Arg756Cys mutation of ATP1A3 causes an atypical form of alternating hemiplegia of childhood with prolonged paralysis and choreoathetosis. BMC Neurol. 16, 174. doi: 10.1186/s12883-016-0680-6

Keryanov, S., and Gardner, K. L. (2002). Physical mapping and characterization of the human Na,K-ATPase isoform, ATP1A4. Gene 292, 151-166. doi: 10.1016/S0378-1119(02)00647-9

Kim, J. H., Sizov, I., Dobretsov, M., and von Gersdorff, H. (2007). Presynaptic Ca2 ${ }^{+}$ buffers control the strength of a fast post-tetanic hyperpolarization mediated by the $\alpha 3 \mathrm{Na}\left(^{+}\right) / \mathrm{K}\left(^{+}\right)$-ATPase. Nat. Neurosci. 10, 196-205. doi: 10.1038/nn1839

Klimanova, E. A., Tverskoi, A. M., Koltsova, S. V., Sidorenko, S. V., Lopina, O. D., Tremblay, J., et al. (2017). Time- and dose dependent actions of cardiotonic steroids on transcriptome and intracellular content of $\mathrm{Na}^{+}$and $\mathrm{K}^{+}$: a comparative analysis. Sci. Rep. 7:45403. doi: 10.1038/srep45403

Kopec, W., Loubet, B., Poulsen, H., and Khandelia, H. (2014). Molecular mechanism of $\left.\mathrm{Na}^{+}\right), \mathrm{K}\left({ }^{+}\right)$-ATPase malfunction in mutations characteristic of adrenal hypertension. Biochemistry 53, 746-754. doi: 10.1021/bi401425g
Kravtsova, V. V., Petrov, A. M., Matchkov, V. V., Bouzinova, E. V., Vasiliev, A. N., Benziane, B., et al. (2016). Distinct $\alpha 2 \mathrm{Na}, \mathrm{K}$-ATPase membrane pools are differently involved in early skeletal muscle remodeling during disuse. J. Gen. Physiol. 147, 175-188. doi: 10.1085/jgp.201511494

Larsen, B. R., Assentoft, M., Cotrina, M. L., Hua, S. Z., Nedergaard, M., Kaila, K., et al. (2014). Contributions of the $\mathrm{Na}\left({ }^{+}\right) / \mathrm{K}\left(^{+}\right)$-ATPase, NKCC1, and Kir4.1 to hippocampal $\left.\mathrm{K}^{+}\right)$clearance and volume responses. Glia 62, 608-622. doi: 10.1002/glia.22629

Lauritzen, M., Dreier, J. P., Fabricius, M., Hartings, J. A., Graf, R., and Strong, A. J. (2011). Clinical relevance of cortical spreading depression in neurological disorders: migraine, malignant stroke, subarachnoid and intracranial hemorrhage, and traumatic brain injury. J. Cereb. Blood Flow Metab. 31, 17-35. doi: 10.1038/jcbfm.2010.191

Laursen, M., Gregersen, J. L., Yatime, L., Nissen, P., and Fedosova, N. U. (2015). Structures and characterization of digoxin- and bufalin-bound $\mathrm{Na}^{+}, \mathrm{K}^{+}$. ATPase compared with the ouabain-bound complex. Proc. Natl. Acad. Sci. U.S.A. 112, 1755-1760. doi: 10.1073/pnas.1422997112

Lecuona, E., Luquin, S., Avila, J., Garcia-Segura, L. M., and Martin-Vasallo, P. (1996). Expression of the $\beta 1$ and $\beta$ 2(AMOG) subunits of the Na,K-ATPase in neural tissues: cellular and developmental distribution patterns. Brain Res. Bull. 40, 167-174. doi: 10.1016/0361-9230(96)00042-1

Li, M., Jazayeri, D., Corry, B., McSweeney, K. M., Heinzen, E. L., Goldstein, D. B., et al. (2015). A functional correlate of severity in alternating hemiplegia of childhood. Neurobiol. Dis. 77, 88-93. doi: 10.1016/j.nbd.2015.02.002

Liu, Y., Lu, Y., and Zhang, X. (2016). A case of rapid-onset dystoniaparkinsonism accompanied by pyramidal tract impairment. BMC Neurol. 16, 218. doi: 10.1186/s12883-016-0743-8

Magyar, J. P., Bartsch, U., Wang, Z. Q., Howells, N., Aguzzi, A., Wagner, E. F., et al. (1994). Degeneration of neural cells in the central nervous system of mice deficient in the gene for the adhesion molecule on Glia, the $\beta 2$ subunit of murine Na,K-ATPase. J. Cell Biol. 127, 835-845. doi: 10.1083/jcb.127.3.835

Marks, M. J., and Seeds, N. W. (1978). A heterogeneous ouabainATPase interaction in mouse brain. Life Sci. 23, 2735-2744. doi: 10.1016/0024-3205(78)90654-9

Martin-Vasallo, P., Dackowski, W., Emanuel, J. R., and Levenson, R. (1989). Identification of a putative isoform of the $\mathrm{Na}, \mathrm{K}$-ATPase $\beta$ subunit. Primary structure and tissue-specific expression. J. Biol. Chem. 264, 4613-4618.

McDermott, J. P., Sanchez, G., Chennathukuzhi, V., and Blanco, G. (2012). Green fluorescence protein driven by the Na,K-ATPase $\alpha 4$ isoform promoter is expressed only in male germ cells of mouse testis. J. Assist. Reprod. Genet. 29, 1313-1325. doi: 10.1007/s10815-012-9876-x

McDermott, J., Sanchez, G., Nangia, A. K., and Blanco, G. (2015). Role of human $\mathrm{Na}, \mathrm{K}-\mathrm{ATP}$ ase $\alpha 4$ in sperm function, derived from studies in transgenic mice. Mol. Reprod. Dev. 82, 167-181. doi: 10.1002/mrd.22454

McDonough, A. A., Velotta, J. B., Schwinger, R. H., Philipson, K. D., and Farley, R. A. (2002). The cardiac sodium pump: structure and function. Basic Res. Cardiol. 97(Suppl. 1), I19-I24. doi: 10.1007/s003950200024

McLean, W. J., Smith, K. A., Glowatzki, E., and Pyott, S. J. (2009). Distribution of the Na,K-ATPase $\alpha$ subunit in the rat spiral ganglion and organ of corti. J. Assoc. Res. Otolaryngol. 10, 37-49. doi: 10.1007/s10162-008-0152-9

Miller, S. S., Steinberg, R. H., and Oakley, B. II. (1978). The electrogenic sodium pump of the frog retinal pigment epithelium. J. Membr. Biol. 44, 259-279. doi: 10.1007/BF01944224

Mishra, N. K., Habeck, M., Kirchner, C., Haviv, H., Peleg, Y., Eisenstein, M., et al. (2015). Molecular mechanisms and kinetic effects of FXYD1 and phosphomimetic mutants on purified human Na,K-ATPase. J. Biol. Chem. 290 , 28746-28759. doi: 10.1074/jbc.M115.687913

Mobasheri, A., Errington, R. J., Golding, S., Hall, A. C., and Urban, J. P. (1997). Characterization of the $\left.\mathrm{Na}^{+}, \mathrm{K}^{+}\right)$-ATPase in isolated bovine articular chondrocytes; molecular evidence for multiple $\alpha$ and $\beta$ isoforms. Cell Biol. Int. 21, 201-212. doi: 10.1006/cbir.1997.0137

Mobasheri, A., Pestov, N. B., Papanicolaou, S., Kajee, R., Cozar-Castellano, I., Avila, J., et al. (2003). Expression and cellular localization of $\mathrm{Na}, \mathrm{K}-$ ATPase isoforms in the rat ventral prostate. BJU Int. 92, 793-802. doi: 10.1046/j.1464-410X.2003.04460.x

Morth, J. P., Pedersen, B. P., Toustrup-Jensen, M. S., Sorensen, T. L., Petersen, J., Andersen, J. P., et al. (2007). Crystal structure of the sodium-potassium pump. Nature 450, 1043-1049. doi: 10.1038/nature06419 
Morth, J. P., Poulsen, H., Toustrup-Jensen, M. S., Schack, V. R., Egebjerg, J., Andersen, J. P., et al. (2009). The structure of the $\mathrm{Na}^{+}, \mathrm{K}^{+}$-ATPase and mapping of isoform differences and disease-related mutations. Philos. Trans. R. Soc. Lond. B Biol. Sci. 364, 217-227. doi: 10.1098/rstb.20 08.0201

Mulkidjanian, A. Y., Bychkov, A. Y., Dibrova, D. V., Galperin, M. Y., and Koonin, E. V. (2012). Origin of first cells at terrestrial, anoxic geothermal fields. Proc. Natl. Acad. Sci. U.S.A. 109, E821-E830. doi: 10.1073/pnas.1117774109

Nam, J. S., Hirohashi, S., and Wakefield, L. M. (2007). Dysadherin: a new player in cancer progression. Cancer Lett. 255, 161-169. doi: 10.1016/j.canlet.2007.02.018

Newton, L. D., Kastelic, J. P., Wong, B., van der Hoorn, and Thundathil, J. (2009). Elevated testicular temperature modulates expression patterns of sperm proteins in Holstein bulls. Mol. Reprod. Dev. 76, 109-118. doi: $10.1002 / \mathrm{mrd} .20934$

Nishimoto, K., Tomlins, S. A., Kuick, R., Cani, A. K., Giordano, T. J., Hovelson, D. H., et al. (2015). Aldosterone-stimulating somatic gene mutations are common in normal adrenal glands. Proc. Natl. Acad. Sci. U.S.A. 112, E4591-E4599. doi: 10.1073/pnas. 1505529112

Noguchi, S., Mutoh, Y., and Kawamura, M. (1994). The functional roles of disulfide bonds in the $\beta$-subunit of $(\mathrm{Na}, \mathrm{K})$ ATPase as studied by site-directed mutagenesis. FEBS Lett. 341, 233-238. doi: 10.1016/0014-5793(94)80463-X

Nyblom, M., Poulsen, H., Gourdon, P., Reinhard, L., Andersson, M., Lindahl, E., et al. (2013). Crystal structure of $\mathrm{Na}^{+}, \mathrm{K}\left({ }^{+}\right)$-ATPase in the $\mathrm{Na}\left({ }^{+}\right)$-bound state. Science 342, 123-127. doi: 10.1126/science.1243352

Ohnishi, T., Yanazawa, M., Sasahara, T., Kitamura, Y., Hiroaki, H., Fukazawa, Y., et al. (2015). Na, K-ATPase $\alpha 3$ is a death target of Alzheimer patient amyloid- $\beta$ assembly. Proc. Natl. Acad. Sci. U.S.A. 112, E4465-E4474. doi: 10.1073/pnas.1421182112

Paciorkowski, A. R., McDaniel, S. S., Jansen, L. A., Tully, H., Tuttle, E., Ghoneim, D. H., et al. (2015). Novel mutations in ATP1A3 associated with catastrophic early life epilepsy, episodic prolonged apnea, and postnatal microcephaly. Epilepsia 56, 422-430. doi: 10.1111/epi.12914

Palmer, C. J., Scott, B. T., and Jones, L. R. (1991). Purification and complete sequence determination of the major plasma membrane substrate for cAMPdependent protein kinase and protein kinase $\mathrm{C}$ in myocardium. J. Biol. Chem. 266, 11126-11130.

Pelzer, N., Blom, D. E., Stam, A. H., Vijfhuizen, L. S., Hageman, A., van Vliet, J. A., et al. (2016). Recurrent coma and fever in familial hemiplegic migraine type 2. A prospective 15-year follow-up of a large family with a novel ATP1A2 mutation. Cephalalgia. doi: 10.1177/0333102416651284. [Epub ahead of print].

Peng, L., Arystarkhova, E., and Sweadner, K. J. (1998). Plasticity of Na,K-ATPase isoform expression in cultures of flat astrocytes: species differences in gene expression. Glia 24, 257-271.

Peters, T. A., Kuijpers, W., and Curfs, J. H. (2001). Occurrence of NaK-ATPase isoforms during rat inner ear development and functional implications. Eur. Arch. Otorhinolaryngol. 258, 67-73. doi: 10.1007/s004050000304

Poulsen, H., Khandelia, H., Morth, J. P., Bublitz, M., Mouritsen, O. G., Egebjerg, J., et al. (2010). Neurological disease mutations compromise a C-terminal ion pathway in the $\left.\mathrm{Na}\left({ }^{+}\right) / \mathrm{K}^{+}\right)$-ATPase. Nature 467, 99-102. doi: 10.1038/nature09309

Rasmussen, H. H., Hamilton, E. J., Liu, C. C., and Figtree, G. A. (2010). Reversible oxidative modification: implications for cardiovascular physiology and pathophysiology. Trends Cardiovasc. Med. 20, 85-90. doi: $10.1016 /$ j.tcm.2010.06.002

Rindler, T. N., Lasko, V. M., Nieman, M. L., Okada, M., Lorenz, J. N., and Lingrel, J. B. (2013). Knockout of the Na,K-ATPase $\alpha 2$-isoform in cardiac myocytes delays pressure overload-induced cardiac dysfunction. Am. J. Physiol. Heart Circ. Physiol. 304, H1147-H1158. doi: 10.1152/ajpheart.00594.2012

Rose, C. R., and Konnerth, A. (2001). NMDA receptor-mediated $\mathrm{Na}^{+}$signals in spines and dendrites. J. Neurosci. 21, 4207-4214. Available online at: http:// www.jneurosci.org/content/21/12/4207

Rosewich, H., Thiele, H., Ohlenbusch, A., Maschke, U., Altmuller, J., Frommolt, P., et al. (2012). Heterozygous de-novo mutations in ATP1A3 in patients with alternating hemiplegia of childhood: a whole-exome sequencing gene-identification study. Lancet Neurol. 11, 764-773. doi: 10.1016/S1474-4422(12)70182-5
Rosewich, H., Weise, D., Ohlenbusch, A., Gartner, J., and Brockmann, K. (2014). Phenotypic overlap of alternating hemiplegia of childhood and CAPOS syndrome. Neurology 83, 861-863. doi: 10.1212/WNL.0000000000 000735

Rossini, G. P., and Bigiani, A. (2011). Palytoxin action on the $\mathrm{Na}\left({ }^{+}\right), \mathrm{K}\left({ }^{+}\right)$-ATPase and the disruption of ion equilibria in biological systems. Toxicon 57, 429-439. doi: 10.1016/j.toxicon.2010.09.011

Roubergue, A., Philibert, B., Gautier, A., Kuster, A., Markowicz, K., et al. (2015). Excellent response to a ketogenic diet in a patient with alternating hemiplegia of childhood. JIMD Rep. 15, 7-12. doi: 10.1007/8904_2013_292

Ruegsegger, C., Maharjan, N., Goswami, A., Filezac de L’Etang, Weis, J., Troost, D., et al. (2016). Aberrant association of misfolded SOD1 with $\mathrm{Na}\left({ }^{+}\right) / \mathrm{K}\left({ }^{+}\right)$ATPaseQ3 impairs its activity and contributes to motor neuron vulnerability in ALS. Acta Neuropathol. 131, 427-451. doi: 10.1007/s00401-015-1510-4.

Scholl, U. I., Healy, J. M., Thiel, A., Fonseca, A. L., Brown, T. C., Kunstman, J. W., et al. (2015). Novel somatic mutations in primary hyperaldosteronism are related to the clinical, radiological and pathological phenotype. Clin. Endocrinol. 83, 779-789. doi: 10.1111/cen.12873

Schwinger, R. H., Bundgaard, H., Muller-Ehmsen, J., and Kjeldsen, K. (2003). The Na, K-ATPase in the failing human heart. Cardiovasc. Res. 57, 913-920. doi: 10.1016/S0008-6363(02)00767-8

Schwinger, R. H., Wang, J., Frank, K., Muller-Ehmsen, J., Brixius, K., McDonough, A. A., et al. (1999). Reduced sodium pump $\alpha 1, \alpha 3$, and $\beta 1$-isoform protein levels and $\mathrm{Na}^{+}, \mathrm{K}^{+}$-ATPase activity but unchanged $\mathrm{Na}^{+}-\mathrm{Ca}^{+}$ exchanger protein levels in human heart failure. Circulation 99, 2105-2112. doi: 10.1161/01.CIR.99.16.2105

Shamraj, O. I., Grupp, I. L., Grupp, G., Melvin, D., Gradoux, N., Kremers, W., et al. (1993). Characterisation of Na/K-ATPase, its isoforms, and the inotropic response to ouabain in isolated failing human hearts. Cardiovasc. Res. 27, 2229-2237. doi: $10.1093 / \mathrm{cvr} / 27.12 .2229$

Shamraj, O. I., and Lingrel, J. B. (1994). A putative fourth $\mathrm{Na}^{+}, \mathrm{K}\left({ }^{+}\right)$-ATPase $\alpha$ subunit gene is expressed in testis. Proc. Natl. Acad. Sci. U.S.A. 91, 12952-12956. doi: 10.1073/pnas.91.26.12952

Shinoda, T., Ogawa, H., Cornelius, F., and Toyoshima, C. (2009). Crystal structure of the sodium-potassium pump at $2.4 \mathrm{~A}$ resolution. Nature 459, 446-450. doi: $10.1038 /$ nature07939

Shrivastava, A. N., Redeker, V., Fritz, N., Pieri, L., Almeida, L. G., Spolidoro, M., et al. (2015). $\alpha$-synuclein assemblies sequester neuronal $\alpha 3-\mathrm{Na}^{+} / \mathrm{K}^{+}$-ATPase and impair $\mathrm{Na}^{+}$gradient. EMBO J. 34, 2408-2423. doi: $10.15252 / \mathrm{embj} .201591397$

Shyjan, A. W., and Levenson, R. (1989). Antisera specific for the $\alpha 1, \alpha 2, \alpha 3$, and $\beta$ subunits of the $\mathrm{Na}, \mathrm{K}$-ATPase: differential expression of $\alpha$ and $\beta$ subunits in rat tissue membranes. Biochemistry 28, 4531-4535. doi: 10.1021/bi00437a002

Skou, J. C. (1957). The influence of some cations on an adenosine triphosphatase from peripheral nerves. Biochim. Biophys. Acta 23, 394-401. doi: 10.1016/0006-3002(57)90343-8

Smedemark-Margulies, N., Brownstein, C. A., Vargas, S., Tembulkar, S. K., Towne, M. C., Shi, J., et al. (2016). A novel de novo mutation in ATP1A3 and childhood-onset schizophrenia. Cold Spring Harbor Mol. Case Stud. 2:a001008. doi: $10.1101 /$ mcs.a001008

Sparrow, J. R., Hicks, D., and Hamel, C. P. (2010). The retinal pigment epithelium in health and disease. Curr. Mol. Med. 10, 802-823. doi: $10.2174 / 156652410793937813$

Spiller, S., and Friedrich, T. (2014). Functional analysis of human $\mathrm{Na}\left({ }^{+}\right) / \mathrm{K}\left({ }^{+}\right)-$ ATPase familial or sporadic hemiplegic migraine mutations expressed in Xenopus oocytes. World J. Biol. Chem. 5, 240-253. doi: 10.4331/wjbc.v5.i2.240.

Stanley, C. M., Gagnon, D. G., Bernal, A., Meyer, D. J., Rosenthal, J. J., and Artigas, P. (2015). Importance of the voltage dependence of cardiac $\mathrm{Na} / \mathrm{K}$ ATPase isozymes. Biophys. J. 109, 1852-1862. doi: 10.1016/j.bpj.2015.09.015

Stindl, J., Tauber, P., Sterner, C., Tegtmeier, I., Warth, R., and Bandulik, S. (2015). Pathogenesis of adrenal aldosterone-producing adenomas carrying mutations of the $\left.\mathrm{Na}\left({ }^{+}\right) / \mathrm{K}^{+}\right)$-ATPase. Endocrinology 156, 4582-4591. doi: 10.1210/en.2015-1466

Sugiura, M., Nakamura, M., Ikoma, Y., Yano, M., Ogawa, K., Matsumoto, H., et al. (2005). High serum carotenoids are inversely associated with serum $\gamma$-glutamyltransferase in alcohol drinkers within normal liver function. $J$. Epidemiol. 15, 180-186. doi: 10.2188/jea.15.180 
Sweadner, K. J., Herrera, V. L., Amato, S., Moellmann, A., Gibbons, D. K., and Repke, K. R. (1994). Immunologic identification of $\mathrm{Na}^{+}, \mathrm{K}\left({ }^{+}\right)$-ATPase isoforms in myocardium. Isoform change in deoxycorticosterone acetate-salt hypertension. Circ. Res. 74, 669-678. doi: 10.1161/01.RES.74.4.669

Sweadner, K. J., Toro, C., Whitlow, C. T., Snively, B. M., Cook, J. F., Ozelius, L. J., et al. (2016). ATP1A3 mutation in adult rapid-onset ataxia. PLoS ONE 11:e0151429. doi: 10.1371/journal.pone.0151429

Sweney, M. T., Newcomb, T. M., and Swoboda, K. J. (2015). The expanding spectrum of neurological phenotypes in children with ATP1A3 mutations, alternating hemiplegia of childhood, rapid-onset dystonia-parkinsonism, CAPOS and beyond. Pediatr. Neurol. 52, 56-64. doi: 10.1016/j.pediatrneurol.2014.09.015

Teo, A. E., Garg, S., Shaikh, L. H., Zhou, J., Karet Frankl, F. E., Gurnell, M., et al. (2015). Pregnancy, primary aldosteronism, and adrenal CTNNB1 mutations. N. Engl. J. Med. 373, 1429-1436. doi: 10.1056/NEJMoa1504869

Tokhtaeva, E., Clifford, R. J., Kaplan, J. H., Sachs, G., and Vagin, O. (2012). Subunit isoform selectivity in assembly of Na,K-ATPase $\alpha-\beta$ heterodimers. J. Biol. Chem. 287, 26115-26125. doi: 10.1074/jbc.M112.370734

Tokhtaeva, E., Munson, K., Sachs, G., and Vagin, O. (2010). N-glycan-dependent quality control of the $\mathrm{Na}, \mathrm{K}-\mathrm{ATPase} \beta(2)$ subunit. Biochemistry 49, 3116-3128. doi: 10.1021/bi100115a

Ujvari, B., Casewell, N. R., Sunagar, K., Arbuckle, K., Wuster, W., Lo, N., et al. (2015). Widespread convergence in toxin resistance by predictable molecular evolution. Proc. Natl. Acad. Sci. U.S.A. 112, 11911-11916. doi: 10.1073 /pnas.1511706112

Urayama, O., Shutt, H., and Sweadner, K. J. (1989). Identification of three isozyme proteins of the catalytic subunit of the Na,K-ATPase in rat brain. J. Biol. Chem. 264, 8271-8280.

Vague, P., Coste, T. C., Jannot, M. F., Raccah, D., and Tsimaratos, M. (2004). C-peptide, $\mathrm{Na}^{+}, \mathrm{K}\left({ }^{+}\right)$-ATPase, and diabetes. Exp. Diabesity Res. 5, 37-50. doi: 10.1080/15438600490424514

Walaas, S. I., Czernik, A. J., Olstad, O. K., Sletten, K., and Walaas, O. (1994). Protein kinase C and cyclic AMP-dependent protein kinase phosphorylate phospholemman, an insulin and adrenaline-regulated membrane phosphoprotein, at specific sites in the carboxy terminal domain. Biochem. J. 304(Pt 2), 635-640. doi: 10.1042/bj3040635

Wetzel, R. K., Arystarkhova, E., and Sweadner, K. J. (1999). Cellular and subcellular specification of $\mathrm{Na}, \mathrm{K}$-ATPase $\alpha$ and $\beta$ isoforms in the postnatal development of mouse retina. J. Neurosci. 19, 9878-9889.

Wetzel, R. K., and Sweadner, K. J. (2001). Immunocytochemical localization of NaK-ATPase $\alpha$ - and $\gamma$-subunits in rat kidney. Am. J. Physiol. Ren. Physiol. 281,
F531-F545. Available online at: http://ajprenal.physiology.org/content/281/3/ F531.long

Winther, A. M., Bublitz, M., Karlsen, J. L., Moller, J. V., Hansen, J. B., Nissen, P., et al. (2013). The sarcolipin-bound calcium pump stabilizes calcium sites exposed to the cytoplasm. Nature 495, 265-269. doi: 10.1038/nature 11900

Zahler, R., Zhang, Z. T., Manor, M., and Boron, W. F. (1997). Sodium kinetics of $\mathrm{Na}, \mathrm{K}-\mathrm{ATPase} \alpha$ isoforms in intact transfected HeLa cells. J. Gen. Physiol. 110, 201-213. doi: 10.1085/jgp.110.2.201

Zhang, M., Zeng, S., Zhang, L., Li, H., Chen, L., Zhang, X., et al. (2014). Localization of $\quad \mathrm{Na}\left({ }^{+}\right)-\mathrm{K}\left({ }^{+}\right)$-ATPase $\alpha / \beta, \quad \mathrm{Na}\left({ }^{+}\right)-\mathrm{K}\left({ }^{+}\right)-$ 2Cl-cotransporter 1 and aquaporin-5 in human eccrine sweat glands. Acta Histochem. 116, 1374-1381. doi: 10.1016/j.acthis.2014. 08.010

Zhang, X. L., Danto, S. I., Borok, Z., Eber, J. T., Martin-Vasallo, P., and Lubman, R. L. (1997). Identification of $\left.\mathrm{Na}\left({ }^{+}\right)-\mathrm{K}^{+}\right)$-ATPase $\beta$-subunit in alveolar epithelial cells. Am. J. Physiol. 272, L85-94.

Zhen, Y., Aardema, M. L., Medina, E. M., Schumer, M., and Andolfatto, P. (2012). Parallel molecular evolution in an herbivore community. Science 337, 1634-1637. doi: 10.1126/science.1226630

Ziff, O. J., and Kotecha, D. (2016). Digoxin: the good and the bad. Trends Cardiovasc. Med. 26, 585-595. doi: 10.1016/j.tcm.2016. 03.011

Zlokovic, B. V., Mackic, J. B., Wang, L., McComb, J. G., and McDonough, A. (1993). Differential expression of Na,K-ATPase $\alpha$ and $\beta$ subunit isoforms at the blood-brain barrier and the choroid plexus. J. Biol. Chem. 268, 8019-8025.

Conflict of Interest Statement: The authors declare that the research was conducted in the absence of any commercial or financial relationships that could be construed as a potential conflict of interest.

The reviewer PMV and handling Editor declared their shared affiliation, and the handling Editor states that the process nevertheless met the standards of a fair and objective review.

Copyright (c) 2017 Clausen, Hilbers and Poulsen. This is an open-access article distributed under the terms of the Creative Commons Attribution License (CC BY). The use, distribution or reproduction in other forums is permitted, provided the original author(s) or licensor are credited and that the original publication in this journal is cited, in accordance with accepted academic practice. No use, distribution or reproduction is permitted which does not comply with these terms. 